Australian

National

University

Crawford School of Public Policy

\title{
CAMA
}

Centre for Applied Macroeconomic Analysis

\section{The Post-Crisis Slump in the Euro Area and the US: Evidence from an Estimated Three-Region DSGE Model}

\section{CAMA Working Paper 10/2016 February 2016}

Robert Kollmann

ECARES, Université Libre de Bruxelles, CEPR and

Centre for Applied Macroeconomic Analysis, ANU

Beatrice Pataracchia

European Commission, Joint Research Centre

Rafal Raciborski

European Commission, DG ECFIN

Marco Ratto

European Commission, Joint Research Centre

Werner Roeger

European Commission, DG ECFIN

Lukas Vogel

European Commission, DG ECFIN 


\section{Abstract}

The global financial crisis (2008-09) led to a sharp contraction in both Euro Area (EA) and US real activity, and was followed by a long-lasting slump. However, the post-crisis adjustment in the EA and the US shows striking differences-in particular, the EA slump has been markedly more protracted. We estimate a three-region (EA, US and Rest of World) New Keynesian DSGE model (using quarterly data for 1999-2014) to quantify the drivers of the divergent EA and US adjustment paths. Our results suggest that financial shocks were key drivers of the 2008-09 Great Recession, for both the EA and the US. The post-2009 slump in the EA mainly reflects a combination of adverse aggregate demand and supply shocks, in particular lower productivity growth, and persistent adverse shocks to capital investment, linked to the continuing poor health of the EA financial system. Adverse financial shocks were less persistent for the US. The financial shocks identified by the model are consistent with observed performance indicators of the EA and US banking systems.

\section{Keywords}

Post-crisis slump, Euro Area, United States, estimated DSGE model, demand and supply shocks and financial shocks

\section{JEL Classification}

F4, F3, E2, E3, E5, E6, C5

\section{Address for correspondence:}

(E) cama.admin@anu.edu.au

\section{ISSN 2206-0332}

The Centre for Applied Macroeconomic Analysis in the Crawford School of Public Policy has been established to build strong links between professional macroeconomists. It provides a forum for quality macroeconomic research and discussion of policy issues between academia, government and the private sector.

The Crawford School of Public Policy is the Australian National University's public policy school, serving and influencing Australia, Asia and the Pacific through advanced policy research, graduate and executive education, and policy impact. 


\title{
The Post-Crisis Slump in the Euro Area and the US: Evidence from an Estimated Three-Region DSGE Model
}

\author{
February 22, 2016 \\ Robert Kollmann (ECARES, Université Libre de Bruxelles, CEPR and CAMA) ${ }^{(*)}$ \\ Beatrice Pataracchia (European Commission, Joint Research Centre) \\ Rafal Raciborski (European Commission, DG ECFIN) \\ Marco Ratto (European Commission, Joint Research Centre) \\ Werner Roeger (European Commission, DG ECFIN) \\ Lukas Vogel (European Commission, DG ECFIN)
}

The global financial crisis (2008-09) led to a sharp contraction in both Euro Area (EA) and US real activity, and was followed by a long-lasting slump. However, the post-crisis adjustment in the EA and the US shows striking differences - in particular, the EA slump has been markedly more protracted. We estimate a three-region (EA, US and Rest of World) New Keynesian DSGE model (using quarterly data for 1999-2014) to quantify the drivers of the divergent EA and US adjustment paths. Our results suggest that financial shocks were key drivers of the 2008-09 Great Recession, for both the EA and the US. The post-2009 slump in the EA mainly reflects a combination of adverse aggregate demand and supply shocks, in particular lower productivity growth, and persistent adverse shocks to capital investment, linked to the continuing poor health of the EA financial system. Adverse financial shocks were less persistent for the US. The financial shocks identified by the model are consistent with observed performance indicators of the EA and US banking systems.

JEL Classification: F4, F3, E2, E3, E5, E6 and C5

Keywords: Post-crisis slump, Euro Area, United States, estimated DSGE model, demand and supply shocks and financial shocks

$\left.{ }^{*}\right)$ Corresponding author. Address: Prof. R. Kollmann, ECARES, CP 114, Université Libre de Bruxelles, 50 Av. Franklin Roosevelt, B-1050 Brussels, Belgium. robert_kollmann@yahoo.com. R. Kollmann is also affiliated with the Globalization and Monetary Policy Institute (Federal Reserve Bank of Dallas).

We are very grateful to Guenter Coenen and Eric Leeper for constructive comments and advice. We also thank workshop participants at the EU Commission, EABCN, MACFINROBODS, and at the North American Winter Meetings of the Econometric Society for useful suggestions. Research support from Alice Albonico, Stefan Hohberger, Filippo Pericoli, and Philipp Pfeiffer is gratefully acknowledged.

The research leading to these results has received funding from the European Community's Seventh Framework Programme (FP7/2007-2013) under grant agreement 'Integrated MacroFinancial Modeling for Robust Policy Design' (MACFINROBODS, grant no. 612796)

The views expressed in this paper are those of the authors and should not be attributed to the European Commission. 


\section{Introduction}

The global financial crisis (2008-09) led to a sharp contraction in both Euro Area (EA) and US real activity, and was followed by a long-lasting slump. However, the post-crisis adjustment in the EA and the US shows striking differences. In particular, the EA slump has been markedly more protracted. As of this writing (2015), EA per capita real GDP remains below its pre-crisis peak. US per capita GDP only recovered to its pre-crisis peak in 2014 and remains noticeably below its pre-crisis trend. Private investment contracted less (as a share of GDP) in the EA than in the US, during the 2008-09 crisis, but in the aftermath of the crisis the EA investment share continued to trend down, while the US investment share began to recover in 2011. Also, postcrisis inflation has been lower in the EA than in the US. (See Section 2 for a detailed discussion of the EA and US post-crisis dynamics.)

There is a heated debate about the causes of these developments. Some commentators argue that the protracted EA slump reflects weak aggregate demand, driven i.a. by restrictive fiscal policy ('austerity'); see, e.g., IMF (2012), De Grauwe (2014) and Stiglitz (2015). Other analysts stress that rigidities in EA product and labor markets may have hampered the rebound of the EA economy, by slowing down sectoral redeployment and the adoption of new technologies (e.g., Fernald (2015)). Several commentators have also suggested that post-crisis deleveraging pressures and financial constraints have contributed to the persistent slump, especially in the EA (e.g., Rogoff (2015)). The supply of credit to the private sector may have been disrupted more persistently in the EA than in the US, due to the continuing poorer health of EA banks (OECD (2014)). EA banks rebuilt their capital much more gradually than US banks, after the crisis; in addition EA bank balance sheets were weakened by the sovereign debt crisis that erupted in 2010-11 (Acharya et al. (2015), Kalemli-Özcan et al. (2015)).

The contribution of this paper is to shed light on these issues and hypotheses using a stateof-the-art estimated dynamic stochastic general equilibrium (DSGE) model. So far, the debate on the EA post-crisis slump has often been polemical, with remarkably little use of evidence-based quantitative models. (Some recent research uses estimated DSGE models to analyze the dynamics of the US economy since the crisis; see discussion below.) The use of an estimated rich DSGE model allows us to recover the shocks that have driven the EA, US and ROW economies - and, hence, we can determine what shocks and transmission mechanisms mattered most and when.

In order to explain the striking post-crisis divergence between the EA and the US, we jointly model these two regions, as well as an aggregate of the Rest of the World (ROW), i.e. we 
consider a three-region model. The EA and US blocks of the model have the same structure, but parameters are allowed to differ across the blocks. The model is estimated using quarterly data for the period 1999q1-2014q4. In order to address the range of views about the post-crisis slump (see above), our model assumes a rich set of demand and supply shocks in goods, labor and asset markets, and it allows for nominal and real rigidities and financial frictions.

Our estimation results suggest that the persistent EA slump reflects a combination of adverse supply and demand shocks, in particular negative shocks to TFP growth and adverse shocks to production capital investment risk premia, linked to the continuing poor health of the EA banking system. Our empirical analysis suggests that fiscal policy (austerity) has not been a major factor delaying the recovery in the EA. EA real activity has benefited from noticeable positive factors during the aftermath of the crisis--however those positive influences were weaker than the adverse supply and demand shocks mentioned above. For example, our model estimates suggest that EA price mark-ups fell during and after the 2008-09 Great Recession, which was reflected in a rise in the EA wage share, and was a driver of low post-crisis EA inflation. An additional factor for low post-crisis inflation in the EA was weak private demand.

According to our estimates, the faster post-crisis rebound of the US economy largely reflects a steady fall in capital investment risk premia, linked to the faster improvement in the health of the US financial system. Furthermore, post-crisis TFP growth fell markedly less in the US than in the EA. In the aftermath of the crisis, US aggregate activity also benefited from more resilient private consumption demand, consistent with faster household deleveraging in the US (compared to the EA). According to our estimates, US fiscal policy was more stimulative than EA fiscal policy during the financial crisis. However, we also identify important factors that slowed down the recovery of the US economy; in particular, US price mark-ups rose during the post-crisis period, which had a negative influence on US output (and a positive effect on US inflation).

Our empirical estimates suggest that ROW real activity during the financial crisis had a noticeable stabilizing effect on EA and US GDP growth. Shock transmission between EA and the US has been weak.

As pointed out above, there is little empirical model-based research on the EA post-crisis slump. By contrast, several recent papers have studied the post-crisis dynamics of inflation and real activity in the US economy, using estimated closed economy DSGE models; see Christiano et al. (2015), Fratto and Uhlig (2015), Lindé et al. (2015) and Del Negro et al. (2015). Like Fratto 
and Uhlig (2015) and Lindé et al. (2015) we find that the zero-lower-bound (ZLB) was not a significant constraint for US and EA monetary policy during the 2008-09 Great Recession and its aftermath. We concur with Christiano et al. (2015) that financial shocks were the key driver of the Great Recession in the US; we find that those shocks matter a great deal for the persistence of the EA slump. A key contribution of our analysis of the US economy is that we model external (international) factors - we show that those factors play a non-negligible role for the US recovery.

As pointed out above, a central contribution of the paper here is the estimation of a largescale multi-country model. By contrast most existing large multi-country models are calibrated (e.g., Coenen et al. (2010)). Jacob and Peersman (2012) and Kollmann (2013) have estimated two-country DSGE models, but those models are much more stylized than the structure here. The model here is closest to Kollmann, Ratto, Roeger in't Veld and Vogel (2015) who estimated a three-country model for Germany, the rest of the Euro Area and the ROW. That model has a detailed German block, and the focus is on developments in that country, while the blocks describing the other two regions are more stylized. By contrast, the model here treats the EA and US at the same level of disaggregation, in order to understand differences in adjustment across these two regions and in order to capture the interaction between these two regions.

Section 2 describes macroeconomic conditions in the EA, the US and ROW in the period 1999-2014. Section 3 gives an overview of the model. Section 4 discussed the econometric approach. Section 5 presents the empirical results. Section 6 concludes.

\section{EA and US macroeconomic and financial conditions, 1999-2014}

Figure 1 plots time series of key macroeconomic variables in the EA and the US in the period 1999-2014, i.e. since the launch of the Euro. Unless stated otherwise, the 'EA' data considered in this paper are aggregates for all countries that were members of the Euro Zone in 2015, less Lithuania (due to missing data). ${ }^{1}$

Panels a. and b. of Figure 1 show EA, US and ROW per capita real GDP (the series are normalized at 100 in 1999). ${ }^{2}$ EA and US per capita output grew at roughly the same rate before

\footnotetext{
1 Thus, the 'EA' aggregate pertains to these 18 countries: Belgium, Germany, Estonia, Ireland, Greece, Spain, France, Italy, Cyprus, Latvia, Luxemburg, Malta, Netherlands, Austria, Portugal, Slovenia, Slovakia, and Finland. In 1999-2014 the EA accounted on average for 74\% of total GDP of all 28 current (2015) member countries of the European Union. This paper focuses on the EA instead of the EU, as EA countries have a common monetary policy. ${ }^{2}$ ROW is an aggregate of 58 countries, including non-EA EU member countries, countries that are neighbors of the EU, G7 countries excluding EA member states and the US, and emerging markets; see the Data Appendix.
} 
the 2008-09 Great Recession. The EA recession started slightly later than the US recession, but both economies experienced approximately the same (relative) contraction, $-5 \%$, in 2008-09, and then began to recover at roughly the same rate. However, the EA recovery was short-lived. In 2010-11 the sovereign debt crisis erupted in EA periphery countries, and the trajectories of EA and US per capital GDP began to diverge: the EA experienced a recession in 2011- 2013, while US output growth returned to pre-crisis rates. EA per capita GDP in 2014 remained 3\% below the pre-crisis peak of 2007, and 20\% below a (log-)linear trend fitted to 1995-2007 per capita GDP. US real per capita GDP stayed below its pre-crisis peak until 2014, but remained about $10 \%$ below a (log-)linear trend fitted to 1995-2007 data. ROW per capita GDP growth has markedly exceeded EA and US growth, during the sample period (see Figure 1, Panel b.). ROW growth accelerated prior to the global crisis. In 2008-09 ROW growth fell sharply, but remained positive; strong ROW growth (4\%-5\% p.a.) resumed in 2010.

The EA-US divergence is also apparent in measured total factor productivity (TFP); see Figure 1, Panel i. EA TFP fell during the Great Recession, and has since then stagnated at a level below its pre-crisis peak. US TFP showed zero growth during the Great Recession, and then started to grow again.

The contraction of the employment rate during the Great Recession was much sharper in the US than in the EA (Panel e.). The US employment rate began to rebound in 2011, but has not yet reached pre-crisis levels, while EA employment continued to slide down after the crisis. The EA wage share (wage earnings/GDP ratio) trended downwards before 2007, and then experienced a marked increase (by close to 4 percentage points) during the Great Recession that has persisted to the end of the sample period (Panel f.). By contrast, the US wage share followed a downward trend throughout the sample period. Average inflation in 1999-2014 was lower in the EA than in the US (Panel k.). US and EA inflation fell during the financial crisis, and rose after the crisis, but stayed below pre-crisis levels.

The dynamics of the components of aggregate demand, too, differs noticeably across the EA and US. Panels c., d. and g. of Figure 1 show EA and US private consumption, private gross investment and net exports, in \% of GDP (Y). (All ratios of variables to GDP discussed in the following paragraphs are ratios of nominal variables.) The EA consumption share (C/Y) fell slightly before the financial crisis, before rising somewhat during the crisis-overall the EA consumption share has been trendless. By contrast, the US consumption share increased steadily by 3.5 percentage points between 1999 and 2011, and then decreased slightly until 2014. 
The private investment share (I/Y) contracted in both the EA and the US, during the 200809 recession. The EA investment share contracted less during the recession, but continued to trend down after 2009. By contrast, the US investment share began to rebound in 2011.

The post-crisis fall in aggregate demand was accompanied by a rise in the US and (especially) EA net exports/GDP ratios (Panel g.). The Euro appreciated steadily against the US dollar until 2008, but the Euro has depreciated by about 10\% since then (Panel h.). The real effective exchange rate (REER) of the EA, too, appreciated until the crisis, and then depreciated mildly. The US effective REER depreciated steadily until 2011, and then appreciated slightly.

Finally, we note that the US primary government deficit rose more sharply than the EA government deficit during the 2008-09 recession, and remained greater than the EA deficit until 2012 (see Panel j.). This suggests that fiscal policy had a more aggressive countercyclical stance in the US than in the EA.

Key EA and US financial variables are plotted in Figure 2. In both regions the household debt/GDP ratio (see Panel a.) rose by roughly 1/3 between 1999 and the financial crisis; that ratio fell after the crisis - the reduction was more pronounced in the US. The debt of non-financial corporations rose more in the EA than in the US, before the financial crisis, and it remained high after the crisis (Panel b.).

The global financial crisis triggered a sizable increase in EA and US non-performing loan (NPL) rates (defined as non-performing bank loans divided by outstanding loans), by about 5 percentage points (Panel c.). After 2009, the EA NPL rate continued to trend upwards (reaching more than 8\% in 2014), while the US NPL rate fell steadily-however, the US NPL rate in 2014 (2\%) remains above the pre-crisis NPL rate. The 2008-09 recession also triggered a persistent rise in EA and US bank loan rate spreads (Panel d.), as well as a tightening of bank lending standards (as measured by loan officer surveys); see Panels e. and f. ${ }^{3}$ During the financial crisis, net credit tightening was stronger in the US than in the EA. However, US credit conditions loosened after 2009, while EA credit continued to tighten. Credit tightness at a given date can be measured by cumulated net credit tightening in preceding periods. Panel f. indicates that US credit tightness fell markedly after 2009, while EA credit tightness continued to increase after 2009. ${ }^{4}$ More

\footnotetext{
${ }^{3}$ The bank loan rate spread is defined as the bank loan rate (to non-financial corporations) minus the money market rate.

${ }^{4}$ Net credit tightening in a given quarter is defined as the percentage of banks that report a tightening of lending standards minus the percentage of banks reporting a loosening of lending standards, in that quarter. EA and US net credit tightening data are available from 2003q1 and from 1999q1, respectively (sources: ECB Euro Area Bank Lending Survey; Federal Reserve Board Senior Loan Officer Opinion Survey on Bank Lending Practices). The
} 
restricted bank credit in the EA is consistent with the NPL problem which plagues EA banks. Aiyar et al. (2015) identify various channels by which high NPL levels restrict the supply of credit; for example, bank profitability suffers because of higher provisions and monitoring costs, which makes it more difficult to raise equity and put resources into new lending. Aiyar et al. (2015) also provide evidence that banks with higher NPLs have higher funding costs.

The evidence in Figure 2 indicates thus that the health of the EA and US banking systems was damaged by the 2008-09 financial crisis; the state of the EA banking system continued to deteriorate after 2009, while the health of the US banking system improved steadily. This is consistent with the fact that policy measures relieving the banking sector from bad loans were pursued earlier and more aggressively in the US; as a result, US banks rebuilt their capital much faster than EA banks after 2008-09 (OECD (2014)). In addition EA bank balance sheets were weakened by the sovereign debt crisis that erupted in 2010-11 (Acharya et al. (2015), KalemliÖzcan et al. (2015)).

\section{Model description}

We consider a three-region world consisting of the EA, US and ROW. The EA and US blocks of the model are rather detailed, while the ROW block is more stylized. The EA and US blocks assume two (representative) households, firms and a government. EA and US households provide labor services to domestic firms. One of the two households in each region has access to financial markets, and she owns her region's firms. The other household has no access to financial markets, does not own financial or physical capital, and each period consumes her disposable wage and transfer income. We refer to these agents as 'Ricardian' and 'hand-to-mouth' households, respectively. Final output in the EA and in the US is generated by perfectly competitive firms that combine domestic and imported intermediate inputs. Intermediates are produced by monopolistically competitive firms using local labor and capital. EA and US wage rates are set by monopolistic trade unions. Nominal intermediate goods prices and nominal wages are sticky. Governments purchase the local final good, make lump-sum transfers to local households, levy labor and consumption taxes and issue debt. All exogenous random variables in

(cumulative) US credit tightness series shown in Panel f. is normalized additively (subtraction of a constant) so that the normalized series equals zero in 2002q4. 
the model follow independent autoregressive processes. We next present the key aspects of the EA model block. The US block has the same structure. ${ }^{5}$

\subsection{EA households}

A household's welfare depends on consumption and hours worked. EA household $i=r, h$ ( $r$ : Ricardian, $h$ : hand-to-mouth) has this period utility function:

$$
U_{t}^{i} \equiv \frac{1}{1-\theta}\left(C_{t}^{i}-\eta^{C} C_{t-1}^{i}\right)^{1-\theta}-s_{t}^{N}\left(C_{t}^{i}\right)^{1-\theta} \frac{1}{1+\theta^{N}}\left(N_{t}^{i}-\eta^{N} N_{t-1}^{i}\right)^{1+\theta^{N}}
$$

with $0<\theta, \theta^{N}, s_{t}^{N}$ and $0<\eta^{C}, \eta^{N}<1 . C_{t}^{i}$ and $N_{t}^{i}$ are consumption and the labor hours of household $i$ in period t, respectively. We assume (exogenous) habit persistence for consumption and labor hours. ${ }^{6} s_{t}^{N}$ is a stationary exogenous shock to the disutility of labor. The subjective discount factor of EA households, $0<\beta_{t, t+1}<1$, too is an exogenous random variable. Date $t$ expected lifetime utility of EA household $i, V_{t}^{i}$, is defined by $V_{t}^{i}=U_{t}^{i}+E_{t} \beta_{t, t+1} V_{t+1}^{i}$.

The EA Ricardian household owns all domestic firms, and she holds domestic and foreign bonds. Her period $t$ budget constraint is:

$$
\left(1+\tau^{C}\right) P_{t} C_{t}^{r}+B_{t+1}^{r}=\left(1-\tau^{N}\right) W_{t} N_{t}^{r}+B_{t}^{r}\left(1+i_{t}^{r}\right)+\operatorname{div}_{t}+T_{t}^{r},
$$

where $P_{t}, W_{t}$, div $v_{t}$ and $T_{t}^{r}$ are the consumption price index, the nominal wage rate, dividends generated by domestic firms, and government transfers received by the Ricardian household. $B_{t+1}^{r}$ denotes the Ricardian household's bond holdings at the end of period t, and $i_{t}^{r}$ is the nominal return on the household's bond portfolio between periods $t-1$ and $t^{7} \tau^{C}$ and $\tau^{N}$ are consumption and labor tax rates, respectively.

The hand-to-mouth household does not trade in asset markets and simply consumes her disposable wage and transfer income. Her budget constraint is: $\left(1+\tau^{C}\right) P_{t} C_{t}^{h}=\left(1-\tau^{N}\right) W_{t} N_{t}^{h}+T_{t}^{h}$.

\footnotetext{
${ }^{5}$ Parameter values are allowed to differ across the EA and the US. The description here abstracts from factor adjustment costs and variable capacity utilization rates assumed in the estimated model. Also, we only present the main exogenous shocks. The detailed model is available in a Not-for-Publication Appendix. The EA and US blocks build on, but are considerably different than, the EU Commission's QUEST model of the EU economy; see Ratto et al., 2009; in't Veld et al. (2015), Kollmann et al. (2015).

${ }^{6}$ To allow for balanced growth, the disutility of labor features the multiplicative term $\left(C_{t}^{h}\right)^{1-\theta}$; this term is treated as exogenous by the household.

${ }^{7}$ The household can hold risk-free one-period bonds denominated in EA, US and ROW currency. The model assumes small convex costs to holding foreign-currency bonds; those costs are rebated to agents in a lump sum fashion. The bond-holding costs pin down the household's bond portfolio in the certainty equivalent (linear) model approximation used below.
} 


\subsection{EA firms}

\subsubsection{EA Intermediate goods producers}

In the EA, there is a continuum of intermediate goods indexed by $j \in[0,1]$. Each good is produced by a single firm. As all EA intermediate goods firms face symmetric decision problems, they make identical choices. Firm $j$ has technology $y_{t}^{j}=\Theta_{t}\left(N_{t}^{j}\right)^{\alpha}\left(K_{t}^{j}\right)^{1-\alpha}$, where $y_{t}^{j}, N_{t}^{j}, K_{t}^{j}$ are the firm's output, labor input and capital stock, respectively. Total factor productivity (TFP) $\Theta_{t}>0$ is exogenous and common to all EA intermediate goods producers. Productivity is driven by a transitory autoregressive component, and by a unit root component whose drift follows a persistent autoregressive process. The law of motion of firm $j$ 's capital stock is $K_{t+1}^{j}=K_{t}^{j}(1-\delta)+I_{t}^{j}$, with $0<\delta<1 ; \quad I_{t}^{j}$ is gross investment. The period $t$ dividend of intermediate $\operatorname{good} \operatorname{firm} j$ is

$$
\operatorname{div}_{t}^{j}=p_{t}^{j} y_{t}-W_{t} N_{t}^{j}-p_{t}^{K} I_{t}^{j}-P_{t} \kappa_{t}^{j},
$$

where $p_{t}^{j}$ and $p_{t}^{K}$ denote the price charged by the firm and the prices of production capital, respectively. At $t$, each firm faces a downward sloping demand curve for her output, with exogenous price elasticity $\varepsilon_{t}>1$ that equals the substitution elasticity between different intermediate good varieties (see below). The firm bears a real cost $\kappa_{t}^{j} \equiv \frac{1}{2} \gamma\left(p_{t}^{j}-(1+\pi) p_{t-1}^{j}\right)^{2} / p_{t}^{j}$ of changing her price, where $\pi$ is the steady state inflation rate.

Firm $j$ maximizes the present value of dividends $V_{t}^{j}=\operatorname{div}_{t}^{j}+E_{t} \rho_{t, t+1}^{j} \cdot\left(P_{t} / P_{t+1}\right) \cdot V_{t+1}^{j}$, where $\rho_{t, t+1}^{j}$ is a stochastic discount factor that is smaller than the intertemporal marginal rate of substitution of the domestic Ricardian household (denoted by $\left.\rho_{t, t+1}^{r}\right): \rho_{t, t+1}^{j}=\left(1-z_{t}\right) \rho_{t, t+1}^{r}$, where $0 \leq z_{t}<1$ is an exogenous random variable. This is a short-cut for capturing financial frictions facing the firm; $Z_{t}$ can, e.g., be interpreted as a 'principal agent friction' between the owner and the management of the firm (Hall (2011)). ${ }^{8}$ The firm's Euler equations for capital is

$$
1=\left(1-z_{t}\right) E_{t} \rho_{t, t+1}^{r}\left(P_{t} / P_{t+1}\right)\left\{\left(1-1 / \varepsilon_{t+1}\right) p_{t+1}^{j} M P K_{t+1}^{j} / p_{t}^{K}+(1-\delta) p_{t+1}^{K} / p_{t}^{K}+\Psi_{t}^{j}\right\},
$$

\footnotetext{
${ }^{8}$ Following Bernanke and Gertler (1999), one can also view $z_{t}$ as a non-fundamental shock that generates an investment bubble, i.e. fluctuations in physical investment and in the price of capital that are not related to (conventional) fundamentals.
} 
where $M P K_{t+1}^{j} \equiv \Theta_{t+1} \alpha\left(K_{t+1}^{j}\right)^{\alpha-1}\left(N_{t+1}^{j}\right)^{1-\alpha}$ is the date $t+1$ marginal product of capital. The term $\Psi_{t}^{j}$ depends on the future marginal price-adjustment cost $\left(\Psi_{t}^{j}\right.$ is zero, in steady state). $Z_{t}$ drives a wedge between the risk-free interest rate and the firm's expected return on physical capital. ${ }^{9}$ We thus refer to $Z_{t}$ as a (capital) 'investment risk-premium'.

Quadratic price adjustment costs imply that the inflation rate of local intermediates, $\pi_{t}=\ln \left(p_{t}^{j} / p_{t-1}^{j}\right)$ obeys an expectational Phillips curve, $\pi_{t}-\pi=\rho^{j} E_{t}\left(\pi_{t+1}-\pi\right)+\vartheta^{j}\left(p_{t}^{j} / M C_{t}-\frac{\varepsilon}{\varepsilon-1}\right)$, up to a linear approximation. Here $M C_{t}^{j}$ is the marginal cost of intermediate good firms and $\varepsilon /(\varepsilon-1)$ is the steady state mark-up factor. $\rho^{j}$ is the steady state subjective discount factor of intermediate good firms, and $\vartheta^{j}>0$ is a coefficient that depends on the cost of changing prices. ${ }^{10}$

\subsubsection{EA production of new capital goods}

New production capital is generated using final output. Let $J_{t}=\Xi_{t} \cdot \xi\left(I_{t}\right)$ be the amounts of EA final output needed to produce $I_{t}$ units of EA capital, respectively. $\xi$ is an increasing, strictly convex functions, while $\Xi_{t}$ is an exogenous shock. The price of production capital is $p_{t}^{K}=\Xi_{t} \xi^{\prime}\left(I_{t}\right) P_{t}$. The dividends of the investment good sector is $\operatorname{div}_{t}^{K}=p_{t}^{K} I_{t}-P_{t} J_{t}$.

\subsubsection{EA final good sector}

The EA final good is produced using the technology $Y_{t}=\left(\left(S_{t}^{d}\right)^{1 / v}\left(D_{t}\right)^{(v /(v-1)}+\left(1-S_{t}^{d}\right)^{1 / v}\left(M_{t}\right)^{(v-1) / v}\right)^{v /(v-1)}$, with $0.5<s_{t}^{d}<1 . D_{t}=\left\{\int_{0}^{1}\left(y_{t}^{j}\right)^{\left(\varepsilon_{t}-1\right) \varepsilon_{t}} d j\right\}^{\varepsilon_{t}\left(\varepsilon_{t}-1\right)}$ is an aggregate of the local intermediates, where $\varepsilon_{t}>1$ is the exogenous substitution elasticity between varieties; $M_{t}$ is a composite of intermediates imported from the US and the ROW. The home bias parameter $s_{t}^{d}$ is an exogenous random variable. The price (=marginal cost) of the final good is $p_{t}=\left(s_{t}^{d}\left(p_{t}^{i}\right)^{1-v}+\left(1-s_{t}^{d}\right)\left(p_{t}^{m}\right)^{1-v}\right)^{1 /(1-v)}$, where $p_{t}^{m}$ is the

\footnotetext{
${ }^{9}$ The firm's Euler equation can be written as $1=\left(1-z_{t}\right) E_{t} \rho_{t, t+1}^{r}\left(1+r_{t+1}^{K}\right)$, where $r_{t+1}^{K}$ is the firm's real return on physical capital between $t$ and $t+1$. The Ricardian household's Euler equation for a nominal one-period risk-free bond with interest rate $i_{t+1}$ is $1=E_{t} \rho_{t, t+1}^{r}\left(P_{t} / P_{t+1}\right)\left(1+i_{t+1}\right)$. Thus, up to a (log-)linear approximation: $i_{t+1}-E_{t} \ln \left(P_{t+1} / P_{t}\right) \cong E_{t} r_{t+1}^{K}-z_{t}$.

${ }^{10}$ The model assumes that export prices are set in producer currency; this implies full pass through of nominal exchange rate changes to export prices expressed in buyer currency. The key results highlighted below are unaffected if instead price setting in buyer currency ('pricing to market') is assumed. This is due to the fact that foreign trade shares are low, in the model here.
} 
import price index. The final good is used for domestic private and government consumption, and for investment.

\subsection{Wage setting in the EA}

We assume an EA trade union that 'differentiates' homogenous EA labor hours provided by the two domestic households into imperfectly substitutable labor services; the union then offers those services to intermediate goods-producing firms--the labor input $N_{t}$ in those firms' production functions is a CES aggregate of these differentiated labor services. The union set wage rates at a mark-up $\mu_{t}^{W}$ over the marginal rate of substitution between leisure and consumption. The wage mark-up is inversely related to the degree of substitution between labor varieties in production. Because of wage adjustment cost, the mark-up is countercyclical. We follow Blanchard and Gali (2007) and allow for real wage inertia; the current period real wage rate set by the union is a weighted average of the desired real wage and the past real wage: $W_{t} / P_{t}=\left(\left(1+\mu_{t}^{W}\right) \cdot m r s_{t}\right)^{1-\xi}\left(W_{t-1} / P_{t-1}\right)^{\xi}$, where $m r s_{t}$ is a weighted average of the two households' marginal rates of substitution between consumption and leisure. The parameter $\xi$ can be interpreted as an index of real wage rigidity. Real wage rigidity is crucial for capturing the high persistence of employment rate fluctuations in both the US and the EA.

\subsection{EA monetary and fiscal policy}

The EA monetary policy (nominal) interest rate $i_{t+1}$ is set at date $t$ by the EA central bank according to the interest rate feedback rule

$$
i_{t+1}=\left(1-\rho^{i}\right) \bar{i}+\rho^{i} i_{t}+\left(1-\rho^{i}\right)\left[\eta^{\pi}\left\{\frac{1}{4} \ln \left(P_{t} / P_{t-4}\right)-\pi\right\}+\eta^{Y} Y_{t}^{g a p}\right]+\varepsilon_{t}^{i},
$$

where $Y_{t}^{g a p}$ is the EA output gap, i.e. the (relative) deviation of actual GDP from potential GDP. ${ }^{11}$ $\varepsilon_{t}^{i}$ is a white noise disturbance.

EA real government consumption, $G_{t}$, is set according to the following fiscal rule:

$$
c_{t}^{G}-C^{G}=\rho^{G}\left(c_{t-1}^{G}-C^{G}\right)+\varepsilon_{t}^{G},
$$

where $c_{t}^{G} \equiv G_{t} / Y_{t}$ is government consumption normalized by GDP, while $\varepsilon_{t}^{G}$ is a white noise shock. Real government transfers to EA households are set according to feedback rules that link

\footnotetext{
${ }^{11}$ Date $t$ potential GDP is defined as GDP that would obtain under full utilization of the date $t$ capital stock and steady state hours worked, if TFP equaled its trend (unit root) component at $t$.
} 
transfers to year-on-year GDP growth, to the real value of government debt and to the government budget deficit. The EA government budget constraint is $B_{t+1}^{g}=\left(1+i_{t}\right) B_{t}^{g}-R_{t}^{g}+P_{t} G_{t}+T_{t}$, where $B_{t+1}^{g}, R_{t}^{g}$ and $T_{t}$ are nominal government debt, tax revenue, and total transfers to households.

\subsection{The ROW block}

The model of the ROW economy is a simplified structure with fewer shocks. Specifically, the ROW block consists of a New Keynesian Phillips curve, a budget constraint for the representative household, demand functions for domestic and imported goods (derived from CES consumption good aggregators), and a production technology that uses labor as the sole factor input. The ROW block abstracts from capital accumulation. In the ROW, there are shocks to labor productivity, mark-ups, the subjective discount rate, the relative preference for domestic vs. imported goods, and to monetary policy.

\subsection{Exogenous shocks}

The estimated model assumes 58 exogenous shocks. Other recent estimated DSGE models likewise assume many shocks (e.g., Kollmann et al. (2015)), as it appears that many shocks are needed to capture the key dynamic properties of macroeconomic and financial data. The large number of shocks is also dictated by the fact that we use a large number of observables (53) for estimation, to shed light on different potential causes of the post-crisis slump. Note that the number of shocks has to be at least as large as the number of observables to avoid stochastic singularity of the model. ${ }^{12}$

\section{Model solution and econometric approach}

We compute an approximate model solution by linearizing the model around its deterministic steady state. Following the recent literature that estimates DSGE models, we calibrate a subset of parameters to match long-run data properties, and we estimate the remaining parameters using

\footnotetext{
${ }^{12}$ We follow the empirical DSGE literature (e.g. Lindé et al. (2015)), and select observables such that each shock has at least one associated observable that is strongly impacted by the shock (e.g. as we assume trade shocks, we use trade data to identify the trade shocks). The number of shocks exceeds the number of observables because we assume that TFP in each region is driven by a combination of transitory and permanent shocks. All shocks have a sufficiently distinct impact on observables so that shock identification is possible.
} 
Bayesian methods. ${ }^{13}$ The observables employed in estimation are listed in the Data Appendix. ${ }^{14}$ The estimation uses quarterly data for the period 1999q1- 2014q4.

We calibrate the model so that steady state ratios of main economic aggregates to GDP match average historical ratios for the EA and the US. The EA (US) steady state ratios of private consumption and investment to GDP are set to 56\% (67\%) and 19\% (17\%), respectively. The steady state shares of EA and US GDP in world GDP are 17\% and 25\%. The steady state trade share $\left(0.5^{*}\right.$ (exports+imports)/GDP) is set at $18 \%$ in the EA and $13 \%$ in the US, and the quarterly depreciation rate of capital is $1.4 \%$ in the EA and $1.7 \%$ in the US. We set the steady state government debt/annual GDP ratio at $80 \%$ of GDP in the EA and $85 \%$ in the US. The EA and US steady state real GDP growth rate and inflation are set at $0.35 \%$ and $0.4 \%$ per quarter, respectively. We set the effective rate of time preferences to $0.25 \%$ per quarter.

\section{Estimation results ${ }^{15}$}

\subsection{Posterior parameter estimates}

The posterior estimates of key model parameters are reported in Table 1. (Estimates of other parameters can be found in the Not-for-Publication Appendix.) The steady state consumption share of the Ricardian household is estimated at 0.70 in the EA and 0.74 in the US. Estimated habit persistence in consumption is high in the EA (0.88) and the US (0.86), which indicates a sluggish adjustment of consumption to income shocks. The risk aversion coefficient is in the range of 1.4 in both regions. The parameter estimates suggest a slightly higher labor supply elasticity in the EA than in the US, while labor habit persistence is lower in the EA. Price elasticities of aggregate imports are sizable for the EA (4.3) and for the US (4.05). The elasticity of substitution between imports of different origins is lower, namely 1.06 between US and ROW goods for the EA and 0.28 between EA and ROW goods for the US (not shown in Table 1). The model estimates also suggest substantial nominal price and wage stickiness, and strong real wage

\footnotetext{
${ }^{13}$ We use the DYNARE software (Adjemian et al., 2011) to solve the linearized model and to perform the estimation.

${ }^{14}$ The observables are not demeaned or detrended prior to estimation. The model is estimated on first differences of real GDP, real demand components and price indices, and on nominal ratios of aggregate demand components to GDP.

${ }^{15}$ The presentation of results below focuses on key parameter estimates, impulse responses and historical decomposition. Additional results can be found in the Not-for-publication Appendix. There, we i.a. report predicted business cycle statistics (standard deviations and cross-correlations of key macro variables) for the EA, US and ROW; these statistics are broadly consistent with empirical statistics. As a robustness check, we also estimated the model over a pre-crisis sub-sample (1999-2007); we find that parameter estimates are close to the ones obtained over the whole sample.
} 
rigidity. Estimated price adjustment costs are lower in the EA, compared to the US, whereas wage stickiness is higher in the EA. Estimated monetary and fiscal policy parameters are quite similar across both regions. The estimated EA and US interest rate rules indicate a strong response of the policy rate to domestic inflation, and a weak response to domestic output. The fiscal feedback rules for government transfers exhibit very weak responses to public debt and deficit levels. The estimates also suggest that most exogenous variables are highly serially correlated. The standard deviation of innovations to TFP, subjective discount factors, price and wage mark-ups and trade shares are sizable.

The model properties discussed in what follows are evaluated at the posterior mode of the model parameters.

\subsection{Dynamic effects of shocks}

Figure 3a-3h shows dynamic responses to shocks that matter most during and after the financial crisis. We begin by discussing effects of EA and US aggregate supply shocks (transitory and permanent TFP shocks), and then consider household saving shocks (modeled as shocks to the Ricardian household's subjective discount factor), as well as shocks to government consumption, and to investment risk premia. Finally, we discuss shocks to uncovered interest parity (between the EA/US and the ROW), shocks to ROW competitiveness, and shocks to ROW aggregate demand. In all cases, the effects of a separate one-time 1\% (0.01) innovation to a single exogenous variable are reported. ${ }^{16}$

Predicted responses to transitory shocks to the level of TFP are standard, in the model here (see Figure 3a). A transitory positive region-specific TFP shock raises domestic GDP, consumption, investment and the real wage rate, and it lowers domestic inflation, and triggers a real exchange rate depreciation (represented in Figure 3 by a rise in the real exchange rate), which induces a substitution of imports by domestic goods, and hence (slightly) lowers foreign output. Price stickiness, consumption habit and investment adjustment costs dampen the expansion of aggregate demand, in the short term. This explains why output rises much less (in relative terms) than TFP, and why the transitory TFP shock lowers employment, on impact. The sluggish adjustment of aggregate demand also explains why a positive TFP shock raises the trade balance of the region that receives the shock.

\footnotetext{
${ }^{16}$ In Figures 3a-3g, the sub-plots in the three left-most columns show responses to shocks originating in the EA; the sub-plots in the three right-most columns show responses to shocks originating in the US. Responses of EA [US] variables: red [black] lines.
} 
A positive permanent TFP (growth rate) shock has a much stronger positive effect on domestic consumption, investment and output than a transitory shock (Figure 3b). The stronger effect on aggregate demand explains why permanent TFP shocks raise hours worked, and why these shocks raise domestic inflation in the short run. ${ }^{17}$ The much stronger effect of a permanent TFP shock on aggregate demand also explains why that shock has a (slight) positive effect on foreign output.

These predicted responses suggest that transitory negative EA and US TFP shocks are not a good candidate for explaining the salient facts about the 2008-09 Great Recession and its aftermath. A transitory fall in TFP would raise inflation and employment and worsen the trade balance (which is inconsistent with the observed fall in inflation and employment and the rise in the EA and US trade balances after the 2008-09 recession). A permanent negative TFP shock could better explain the post-crisis data: such a shock is predicted by the model to lead to a persistent decline in output and employment and a temporary decrease in inflation (especially in the US). However, a permanent negative TFP shock fails to generate a strong decline in the investment/GDP ratio (as observed in the crisis and post-crisis data), or a trade balance improvement.

As shown in Figure 3c, a positive shock to private saving (a rise in the subjective discount factor) lowers domestic consumption. The shock triggers a fall in domestic and foreign GDP and inflation, it improves the trade balance, and it crowds in domestic and foreign investment. Thus, while positive private saving shocks might have driven the fall in inflation and the rise in trade balances during/after the crisis, those shocks fail to account for the slump in investment. Because of their predicted positive effect on investment, positive saving shocks likewise fail to generate a persistent decline in GDP growth.

Predicted responses to fiscal shocks are standard, in the model here. A rise in government purchases increases domestic output, and has a very small positive effect on foreign output (Figure 3d). Domestic and foreign consumption and investment are crowded out by a rise in government purchases. Thus, fiscal consolidation is a possible candidate for explaining the postcrisis output slump. However, the model-predicted crowding in of consumption and investment

\footnotetext{
${ }^{17}$ The rise in US inflation is more persistent. The permanent US TFP shock boosts aggregate demand more than the EA shock. This reflects the fact that the US TFP growth rate is more persistent than EA TFP growth; see Table 2. Also, the estimated steady state consumption share of Ricardian (forward-looking) households is higher in the US than in the EA, and estimated consumption habit persistence is weaker in the US.
} 
generated by a fiscal consolidation seems inconsistent with the actual slump in consumption and investment. $^{18}$

A rise in the investment risk premium is predicted to lower domestic investment, as well as domestic and foreign output (see Figure 3e). The fall in aggregate demand induced by the shock lowers labor demand, and thus employment and wages fall. In the short term, the shock lowers inflation. A positive investment risk premium shock generates responses that are consistent along several dimensions with the post-crisis experience: it induces a strong decline of investment relative to GDP; it also generates a highly persistent fall in GDP and a decline in inflation. However, private consumption is crowded in by a positive investment risk premium shock, which suggests that not all facts can be accounted for by this shock. ${ }^{19}$

Figure 3f shows dynamic responses to a shock to the interest parity condition between the Euro and the ROW currency, namely a fall in the risk premium on EA bonds (relative to ROW bonds). This shock appreciates the Euro on impact against the ROW currency, as well as against the US dollar. In response to this, the EA trade balance deteriorates. EA output falls, but EA consumption and investment rise. The Euro appreciation is also accompanied by a fall in EA inflation.

An increase in ROW export competitiveness in the EA (modeled as a fall in the export price mark-up charged by ROW producers in the EA) raises EA imports, and it boosts EA investment (see Figure 3g). EA inflation falls, the Euro depreciates, and EA output falls. (Analogous responses are generated by an increase in ROW export competitiveness in the US.)

Finally, Figure 3h shows dynamic responses to a positive private saving shock in the ROW (i.e. a negative ROW aggregate demand shock). That shock appreciates the EA and US real exchange rate, and it triggers a rise in EA and US consumption and investment, and a deterioration in these regions' trade balances.

The results in this section suggest that a combination of various shocks is required to explain the major stylized facts of the EA and the US recovery. The next section disentangles the role of key shocks using estimated historical shock decompositions.

\footnotetext{
${ }^{18}$ Interestingly, the fiscal multiplier is slightly higher in the US than in the EA; this is mainly a consequence of the stronger price rigidity in the US, and of the weaker inflation response in the estimated US monetary policy rule.

${ }^{19}$ Like for a positive private saving shock, the short term real wage response is positive in the EA while it turns negative immediately in the US. This is again a result of the price and wage adjustment speeds that differ across regions.
} 


\subsection{Decomposing EA and US historical time series, 1999-2014}

To quantify the role of different shocks as drivers of endogenous variables in the period 19992014, we plot the estimated contribution of the different shocks to historical time series. Figure 4 shows historical decompositions of the following EA and US variables: the year-on-year growth rate of real GDP and of the GDP deflator, and the trade balance/GDP ratio. The continuous lines show historical series from which sample averages have been subtracted. The vertical black bars show the contribution of a different group of shocks (see below) to the data, while stacked light bars show the contribution of the remaining shocks. Bars above the horizontal axis represent positive shock contributions, while bars below the horizontal axis show negative contributions. The sum of all shock contributions equals the historical data.

The decompositions of EA variables in Figure 4 (see left-hand Panels) plot the contributions of the following (groups of) exogenous variables originating in the EA: (1) permanent and transitory shocks to EA TFP ('TFP EA'); (2) shocks to the EA investment risk premium; (3) EA price mark-up shocks; (4) EA wage mark-up shocks; (5) shocks to subjective discount factors of EA households ('Private saving shock EA'); (6) EA fiscal policy shocks (i.e. innovations to the fiscal policy decision rules); (7) EA monetary policy shocks; (8) interest parity shocks between the EA and the ROW ('Bond premium EA vs ROW'); (9) interest parity shocks between the US and the ROW ('Bond premium US vs ROW'); (10) shocks to the worldwide relative preference for EA-produced goods versus non-EA goods, and price mark-up shocks for exports and imports ('trade shocks'). In addition, we show contributions of all other non-trade related shocks that originate in the US ('Shocks US'), and of all non-trade-related shocks that originate in the ROW ('Shocks ROW'). The remaining shocks are less important than the shocks listed above, and are hence combined in a category labelled 'Others'.

Shock decompositions for US variables (see right-hand Panels in Fig. 4) use an analogous grouping of shocks.

The historical shock decompositions suggest that in the EA (and also in the US), the precrisis boom was largely driven by negative shocks to investment risk premia (see Figure 4a). Beginning in 2008, important adverse shocks occurred. Our estimates suggest that the EA growth slowdown in 2008-09 is largely due to: (i) an increase in the EA investment risk premium; (ii) a decline in EA TFP growth that represents a permanent level shift; (iii) negative trade shocks. ROW real activity during the 2008-09 financial crisis had a noticeable stabilizing effect on EA GDP growth. The crisis was followed in 2010 by a relatively rapid partial recovery due to a fall in 
risk premia (possibly linked to policy measures to stabilize the financial system). However, in 2011 the EA was hit by a further rise in the investment risk premium, with an adverse effect on investment and GDP. We interpret this second rise in the investment risk premium as a consequence of the sovereign debt crisis that weakened EA bank balance sheets, and thus reduced the supply of credit to the corporate sector and to households, which then lowered corporate investment and household (residential) investment. See Kalemli-Özcan et al. (2015) for micro evidence on this transmission channel of the sovereign debt crisis.

Shocks to EA price and wage mark-ups were less important for the post-2009 dynamics than TFP and investment risk premium shocks; overall, price mark-ups fell after 2009, which dampened the fall in GDP growth. In the EA, positive growth contributions from other sources were very limited after 2009. We identify a small increase in the external Euro risk premium that generated a modest growth impulse via Euro depreciation. Shocks originating in the US had a negligible effect on EA GDP growth.

Our estimates suggest that EA monetary policy shocks had a weak stabilizing effect on GDP growth until 2013. Note that we estimate a linearized version of the model in which the zero lower bound (ZLB) on the nominal policy interest rate is not imposed as a constraint on monetary policy. Estimated monetary policy shocks (disturbances to the interest rate rule) are positive in 2013-14, when the EA policy rate reached levels close to zero. This suggests that, in the EA, the ZLB was binding in 2013-14. ${ }^{20}$

We also find that EA fiscal policy shocks had a slight stimulative effect at the start of the Great Recession in 2008, and a slight contractionary effect before the start of the sovereign debt crisis; overall, the effect of EA fiscal policy was neutral. Thus, fiscal 'austerity' is not to blame for the EA post-crisis slump. ${ }^{21}$

The investment risk premium shock is not only important for explaining EA GDP growth, but is needed to explain the fluctuations in physical investment. The investment risk premium

\footnotetext{
${ }^{20}$ The policy rate implied by the policy rule, without disturbance, is negative in $2013-14$, so that a positive interest rate disturbance is needed to match the observed policy rate.

${ }^{21}$ The omission of the ZLB constraint implies that our empirical analysis may understate the impact of fiscal shocks on real activity (see, e.g., Coenen et al. (2012)). In the Not-for-Publication Appendix, we study the impact of fiscal shocks in a model variant (solved using the Guerrieri and Iacoviello (2015) algorithm) in which the ZLB is imposed as an occasionally binding constraint on monetary policy. That analysis confirms that the ZLB was binding in the EA in 2013-14, and it finds that the effect of fiscal shocks to growth was slightly negative in 2013 and 2014 (accounting for $0.25 \%$ and $0.10 \%$ reductions in GDP growth in 2013 and 2014, respectively). Importantly, we find that imposing the ZLB constraint has a negligible effect on the response of the economy to TFP and investment risk premium shocks; it does not affect the result that these shocks were the most important driver of EA GDP growth during and after the financial crisis.
} 
shock also helps to explain the dynamics of the EA trade balance before and after 2009 (see below). The adverse EA investment risk premium shocks during the crisis had a strong disinflationary effect (see Figure 4b), but that effect was largely offset by the fall in TFP; this explains the muted decline of EA inflation during the 2008-09 crisis. The persistently low postcrisis inflation rate is largely driven by a fall in price mark-ups, and by adverse saving and trade shocks (including oil prices). These effects were only partly offset by monetary policy. Fiscal policy was not a main driver of the persistent fall in post-crisis EA inflation.

The EA trade balance rose significantly and persistently in 2012, after having been stable since the beginning of the sample period. During the global 2008-09 crisis, the EA trade balance showed little change because of the simultaneous contraction of aggregate demand in the EA and in its trading partners (see Figure 4c). The weakness of EA aggregate demand after 2011, combined with the strong ROW recovery and the depreciation of the Euro (explained in the model by an increase in the risk premium on Euro-denominated bonds) then lead to a marked increase in the EA trade balance.

Investment risk premium shocks are even more dominant for US GDP growth than for EA growth (Figure 4a). Those shocks account almost fully for the 2008-09 output contraction. Importantly, the adverse investment risk premium shock was more short-lived in the US than in the EA. This is one of the key factors that explain the better post-crisis GDP performance of the US.

Figure 5 shows smoothed estimates of EA and US investment risk premia (see continuous lines). Both premia fell prior to the crisis, and rose sharply during the financial crisis--the estimated US investment risk premium rose more than the EA premium. In the aftermath of the financial crisis, the US investment risk premium fell gradually and steadily, but remained above its pre-crisis level. After the crisis, the estimated EA investment risk premium initially fell more than the US premium. However, the EA investment risk premium rose again sharply after the eruption of the sovereign debt crisis in 2011, and showed no sign of reverting to its pre-crisis level. It seems plausible that the different post-crisis paths of the EA and US investment risk premia are linked to the poorer health of the EA financial system that disrupted the supply of credit to the private sector more persistently in the EA than in the US (see discussion in Section 2). In fact, estimated investment risk premia are highly positively correlated with the indicators of intermediation frictions presented in Section 2. To illustrate this, Figure 5 also plots the 
cumulated net credit tightening series for the EA and the US (see dashed lines). ${ }^{22}$ The correlations of the estimated EA investment risk premium with the EA cumulated net credit tightening series and with the EA bank loan rate spread are 0.78 and 0.89 , respectively. For the estimated US investment risk premium, the corresponding correlations (with US credit tightness and the US loan rate spread) are 0.86 and 0.92 , respectively. Note, especially, that the estimated investment risk premia match the fact that, during the financial crisis, the loan rate spread and credit tightness rose more sharply in the US than in the EA; the estimated premia also capture the steady improvement in US banking indicators after the crisis, and the deterioration in EA banking indicators after the outbreak of the sovereign debt crisis.

Positive private saving shocks and positive price mark-up shocks, too, contributed noticeably to the US output collapse in the 2008-09 crisis. The US private saving shock might be a proxy for the strong household debt deleveraging that began during the crisis (see Figure $2 \mathrm{a}$ ). ${ }^{23}$ Household saving shocks and adverse investment risk premium shocks contributed importantly to the drop in US inflation during the crisis (Figure 4b). However, the impact of these shocks on inflation was partly offset by a rise in US price mark-ups, together with countercyclical fiscal and monetary policy measures. In the aftermath of the crisis, inflation rebounded faster in the US than in the EA. The role of price mark-ups in muting the fall in US inflation during and after the crisis is consistent with the estimated DSGE model presented by Fratto and Uhlig (2014).

The US entered the financial crisis with a persistent trade deficit. Our historical decomposition suggests that the deficit was largely drive by positive ROW saving shocks, which is consistent with Bernanke's (2005) 'saving glut' hypothesis. In 2008, the US trade balance increased abruptly. This was largely driven by the positive US investment risk premium and saving shocks (Figure 4c). After 2009, the steady fall in the US investment risk premium lowered the US trade balance; however, the US trade balance remained above its pre-crisis level, due to persistent positive US saving shocks and a strong recovery in ROW demand.

\footnotetext{
${ }^{22}$ Empirical cumulated net credit tightening shown in Figure 5 are adjusted (using a linear transformation) so that the mean and standard deviation of the adjusted series equals the corresponding moments of the estimated investment risk premium.

${ }^{23}$ Albuquerque et al. (2014) document the rapid post-crisis adjustment of US household debt, and argue that it was completed in 2012.
} 


\section{Conclusion}

We have estimated a three-region (EA, US and Rest of World) New Keynesian DSGE model to quantify the drivers of the divergent EA and US adjustment paths during the aftermath of the global financial crisis. Our analysis reveals that the slow post-crisis recoveries in the US and EA have both common and idiosyncratic components. An important common feature is the strong rise in investment risk premia during the 2008-09 recession that put an end to a pre-crisis investment boom. The model-based estimates of investment risk premia are consistent with various performance indicators of the EA and US banking systems. An important additional contributing factor of the persistent post-2009 EA slump has been the slowdown of TFP growth. Private saving shocks and fiscal austerity are much less important for explaining low EA growth according to our estimates; however, private saving shocks are important for the post-crisis slowdown of inflation. 


\section{References}

Acharya, Viral, Itamar Drechsel and Philip Schnabl, 2015. A Pyrrhic Victory - Bank Bailouts and Sovereign Credit Risk. Journal of Finance 69, 2689-2739.

Adjemian, Stéphane , Houtan Bastani, Michel Juillard, Frédéric Karamé, Ferhat Mihoubi, George Perendia, Johannes Pfeifer, Marco Ratto and Sébastien Villemot, 2011. Dynare: Reference Manual, Version 4. Dynare Working Papers, 1, CEPREMAP

Aiyar, Shekar, Wolfgang Bergthaler, Jose M. Garrido, Anna Ilyina, Andreas Jobst, Kenneth Kang, Dmitriy Kovtun, Yan Liu, Dermot Monaghan and Marina Moretti, 2015. A Strategy for Resolving Europe's Problem Loans. IMF Staff Discussion Note SDN/15/19.

Albuquerque, Bruno, Ursel Bachmann and Georgi Krustev, 2014. Has US Household Deleveraging Ended? A Model-Based Estimate of Equilibrium Debt. ECB Working Paper 1643.

Bernanke, Ben, 2005. Sandridge Lecture, Virginia Association of Economists.

Bernanke, Ben and Mark Gertler, 1999. Monetary Policy and Asset Price Volatility. Federal Reserve Bank of Kansas City Economic Review, 17-51.

Blanchard, Olivier and Jordi Galí, 2007. Real Wage Rigidities and the New Keynesian Model. Journal of Money, Credit and Banking 39 (S1), 35-65.

Christiano, L., M. Eichenbaum and M. Trabandt, 2015. Understanding the Great Recession. American Economic Journal: Macroeconomics 7, 110-167.

Coenen, Günter, Giovanni Lombardo, Frank Smets and Roland Straub, 2010. International Transmission and Monetary Policy Cooperation. In: International Dimensions of Monetary Policy, Jordi Gali and Mark Gertler (eds), NBER, Cambridge, M.A., Chapter 3, pp. 157-192.

Coenen, Günter, Chris Erceg, Charles Freedman, Davide Furceri, Michael Kumhof, René Lalonde, Douglas Laxton, Jesper Lindé, Annabelle Mourougane, Dirk Muir, Susanna Mursula, Carlos de Resende, John Roberts, Werner Roeger, Stephen Snudden, Mathias Trabandt and Jan in't Veld, 2012. Effects of fiscal stimulus in structural models. American Economic Journal: Macroeconomics 4, 22-68.

De Grauwe, Paul, 2014. Stop Structural Reforms, Start Public Investments.

Del Negro, Marco, Marc Giannoni and Frank Schorfheide, 2015. Inflation in the Great Recession and New Keynesian Models, American Economic Journal: Macroeconomics 7, 168-196.

Fernald, John, 2015. The Pre-Global-Financial-Crisis Slowdown in Productivity. Working Paper.

Fratto, Chiara and Harald Uhlig, 2014. Accounting for Post-Crisis Inflation and Employment: A Retro Analysis, NBER Working Paper 20707.

Guerrieri, Luca and Matteo Iacoviello, 2015. OccBin: A Toolkit for Solving Dynamic Models With Occasionally Binding Constraints Easily, Journal of Monetary Economics 70, 22-38.

Hall, Robert, 2011. The High Sensitivity of Economic Activity to Financial Frictions. Economic Journal 121, 351-378.

International Monetary Fund, 2012. World Economic Outlook (October).

in't Veld, Jan, Robert Kollmann, Beatrice Pataracchia, Marco Ratto and Werner Roeger, 2014. International Capital Flows and the Boom-Bust Cycle in Spain. Journal of International Money and Finance 48, 314-335.

Jacob, Punnoose and Gert Peersman, 2013. Dissecting the Dynamics of the US Trade Balance in an Estimated Equilibrium Model. Journal of International Economics 90, 302-315.

Kalemli-Özcan, Sebnem, Luc Laeven and David Moreno, 2014. Debt Overhang in Europe: Evidence from Firm-Bank-Sovereign Linkages. Working Paper, University of Maryland.

Kollmann, Robert, Jan in't Veld, Marco Ratto, Werner Roeger and Lukas Vogel, 2015. What Drives the German Current Account? And How Does it Affect Other EU Member States? Economic Policy 40, 47-93. 
Kollmann, Robert, 2013. Global Banks, Financial Shocks and International Business Cycles: Evidence from an Estimated Model, Journal of Money, Credit and Banking 45 (S2), 159-195.

Lindé, Jesper, Frank Smets and Rafael Wouters, 2015. Challenges for Macro Models Used at Central Bank. Working Paper.

OECD, 2014. Economic Surveys: Euro Area.

Ratto Marco, Werner Roeger and Jan in 't Veld, 2009. QUEST III: An Estimated Open-Economy DSGE Model of the Euro Area with Fiscal and Monetary Policy, Economic Modelling, 26, 222-33.

Rogoff, K., 2015. Debt Supercycle, Not Secular Stagnation. VoxEU.

Stiglitz, Joseph, 2015. Les dégâts induits par la crise sont durables. In: Le Soir (Bruxelles). September 2, 2015, pp.14-15. 
Table 1. Prior and posterior distributions of key estimated model parameters

\begin{tabular}{|c|c|c|c|c|c|c|c|}
\hline & \multicolumn{4}{|c|}{ Posterior distributions } & \multirow{2}{*}{\multicolumn{3}{|c|}{ Prior distributions }} \\
\hline & \multicolumn{2}{|c|}{ EA } & \multicolumn{2}{|c|}{ US } & & & \\
\hline & Mode & Std & Mode & Std & Distrib. & Mean & Std \\
\hline (1) & (2) & (3) & (4) & (5) & (6) & (7) & (8) \\
\hline \multicolumn{8}{|l|}{ Preferences } \\
\hline Consumption habit persistence & 0.88 & 0.07 & 0.86 & 0.06 & B & 0.5 & 0.2 \\
\hline Labor habit persistence & 0.38 & 3.13 & 0.85 & 0.10 & B & 0.5 & 0.2 \\
\hline Risk aversion & 1.47 & 0.87 & 1.37 & 0.61 & G & 1.5 & 0.2 \\
\hline Labor supply elasticity & 2.32 & 4.91 & 2.10 & 3.74 & G & 2.5 & 0.5 \\
\hline Import price elasticity & 4.30 & 0.71 & 4.05 & 0.76 & G & 2 & 1 \\
\hline \multicolumn{8}{|c|}{ Steady state consumption share of Ricardian households } \\
\hline & 0.70 & 0.03 & 0.74 & 0.04 & B & 0.65 & 0.05 \\
\hline \multicolumn{8}{|l|}{ Nominal and real frictions } \\
\hline Price adjustment cost & 23.2 & 10.1 & 57.4 & 36.8 & G & 60 & 40 \\
\hline Nominal wage adj. cost & 4.69 & 8.22 & 2.93 & 4.71 & G & 5 & 2 \\
\hline Real wage rigidity & 0.97 & 0.06 & 0.96 & 0.05 & $\mathrm{~B}$ & 0.5 & $0 . \overline{2}$ \\
\hline \multicolumn{8}{|l|}{ Monetary policy } \\
\hline Interest rate persistence & 0.85 & 0.03 & 0.83 & 0.03 & B & 0.7 & 0.12 \\
\hline Response to inflation & 2.23 & 0.56 & 1.76 & 0.24 & B & 2 & 0.4 \\
\hline Response to GDP & 0.08 & 0.05 & 0.07 & 0.02 & B & 0.5 & 0.2 \\
\hline \multicolumn{8}{|l|}{ Fiscal policy } \\
\hline Transfer persistence & 0.97 & 0.05 & 0.96 & 0.07 & B & 0.7 & 0.1 \\
\hline Transfer response to deficit & -0.01 & 0.00 & -0.01 & 0.01 & B & -0.03 & 0.01 \\
\hline Transfer response to debt $-\mathrm{C}$ & -0.001 & 0.00 & -0.001 & 0.00 & B & -0.001 & 0.001 \\
\hline Gov. consumption persistence & 0.95 & 0.01 & 0.95 & 0.02 & B & 0.7 & 0.1 \\
\hline \multicolumn{8}{|c|}{ Autocorrelations of forcing variables } \\
\hline Temporary TFP & 0.78 & 0.12 & 0.50 & 0.16 & B & 0.5 & 0.2 \\
\hline Permanent TFP growth & 0.95 & 0.12 & 0.97 & 0.04 & B & 0.8 & 0.1 \\
\hline Subjective discount factor & 0.80 & 0.10 & 0.79 & 0.08 & B & 0.5 & 0.2 \\
\hline Investment risk premium & 0.94 & 0.05 & 0.96 & 0.03 & B & 0.5 & 0.2 \\
\hline Domestic price mark-up & 0.24 & 0.15 & 0.76 & 0.12 & B & 0.5 & 0.2 \\
\hline Trade share & 0.93 & 0.02 & 0.85 & 0.05 & B & 0.5 & 0.2 \\
\hline Export price mark-up & 0.94 & 0.02 & 0.85 & 0.04 & B & 0.5 & 0.2 \\
\hline ROW export price mark-up & 0.98 & 0.01 & 0.98 & 0.01 & B & 0.5 & 0.2 \\
\hline \multicolumn{8}{|c|}{ Standard deviations (\%) of innovations to forcing variables } \\
\hline Monetary policy & 0.09 & 0.01 & 0.12 & 0.01 & G & 1.00 & 0.40 \\
\hline Gov. consumption & 0.06 & 0.01 & 0.13 & 0.01 & $\mathrm{G}$ & 1.00 & 0.40 \\
\hline Gov. transfers & 0.10 & 0.01 & 0.23 & 0.02 & G & 1.00 & 0.40 \\
\hline Temporary TFP & 0.92 & 0.17 & 1.45 & 0.35 & G & 0.50 & 0.20 \\
\hline Permanent TFP growth & 0.02 & 0.05 & 0.03 & 0.03 & G & 0.02 & 0.008 \\
\hline Subjective discount factor & 0.96 & 0.92 & 1.19 & 0.91 & G & 0.10 & 0.40 \\
\hline Investment risk premium & 0.18 & 0.09 & 0.16 & 0.08 & G & 1.00 & 0.40 \\
\hline Domestic price mark-up & 3.65 & 1.55 & 3.80 & 2.93 & G & 2.00 & 0.80 \\
\hline Trade share & 5.83 & 0.91 & 6.51 & 1.07 & G & 2.00 & 0.80 \\
\hline Export price mark-up & 0.61 & 0.07 & 0.81 & 0.04 & G & 1.00 & 0.40 \\
\hline ROW export price mark-up & 4.24 & 0.47 & 2.45 & 0.18 & $\mathrm{G}$ & 1.00 & 0.40 \\
\hline
\end{tabular}

Notes: Cols. (1) lists model parameters. Cols. (2)-(3) and Cols. (4)-(5) show the mode and the standard deviation (Std) of the posterior distributions of EA parameters and of US parameters, respectively. Cols. (6) (labelled 'Distrib.') indicates the prior distribution function (B: Beta distribution; G: Gamma distribution). Identical priors are assumed for EA and US parameters. 


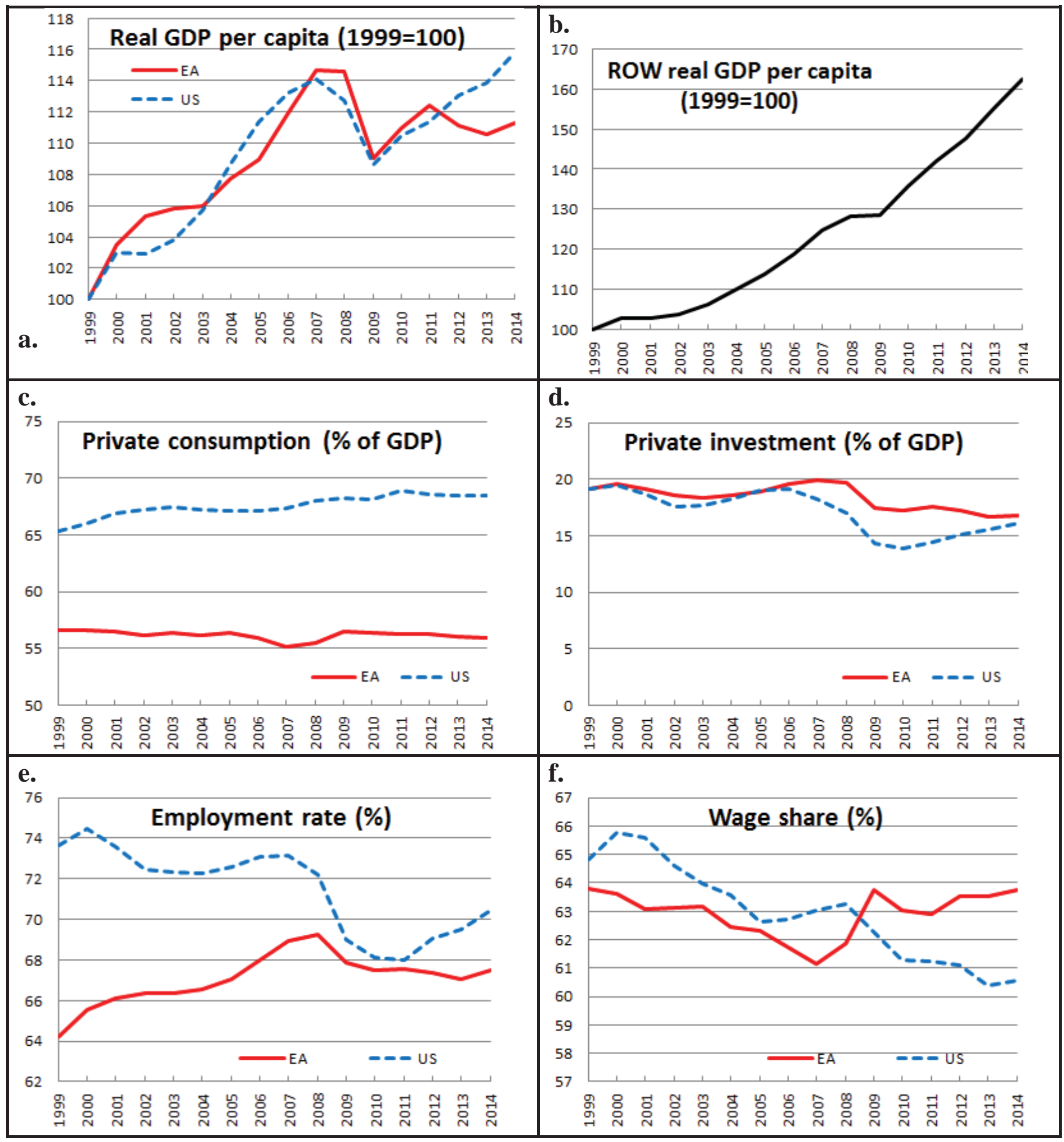




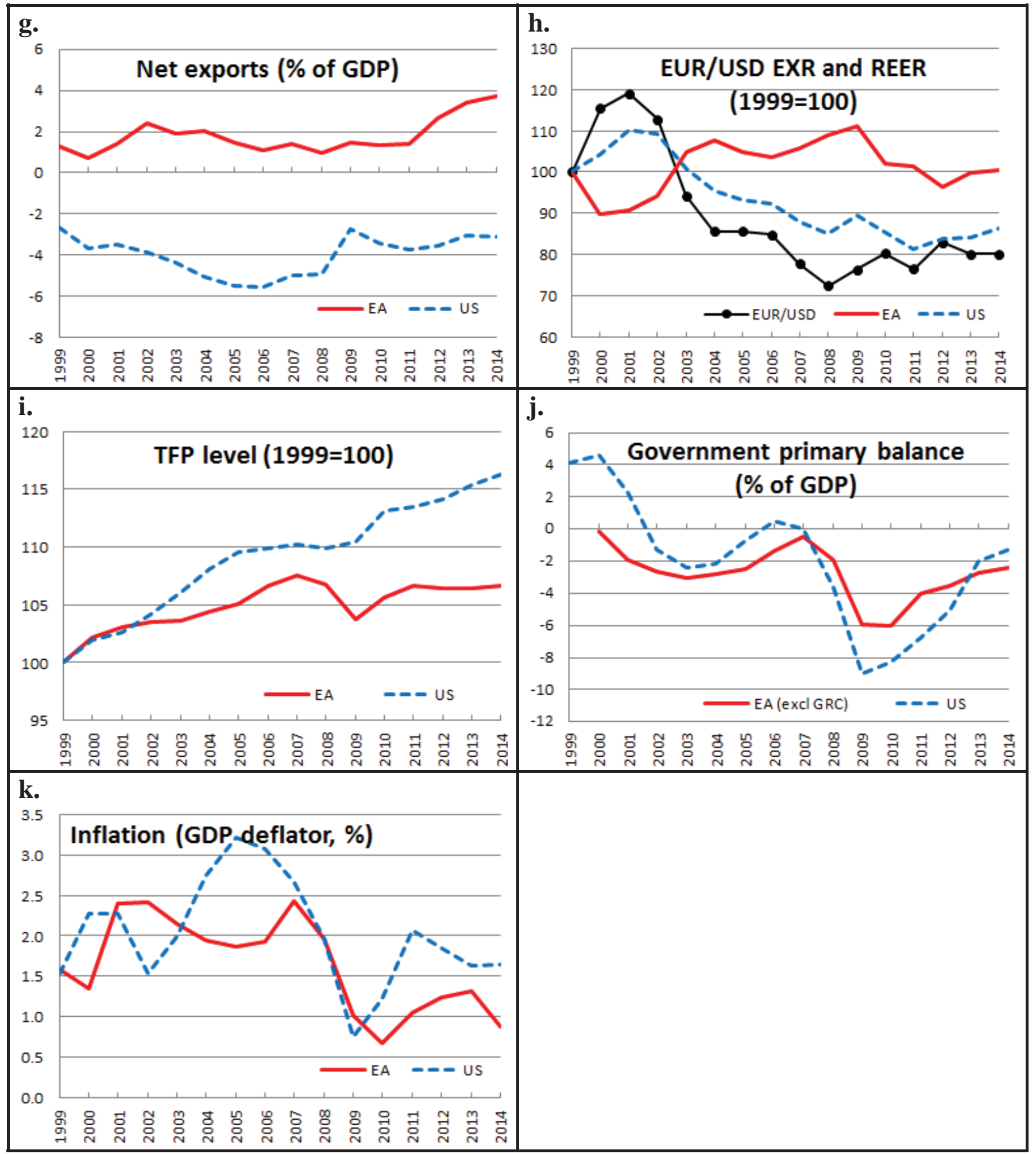

Figure 1. Macroeconomic conditions in the EA, US and ROW

Notes: The employment rate is total employment (persons) divided by the working-age (15-64) population. The wage share is compensation of employees adjusted for the imputed compensation of self-employed in per cent of GDP at factor costs. An increase in the EUR/USD exchange rate (Fig. 1.h) corresponds to a EUR depreciation against the USD; a REER increase corresponds to real effective appreciation in the respective region. REERs are based on CPIs and a group of 42 countries. The EA government balance excludes Greece due to missing data. 


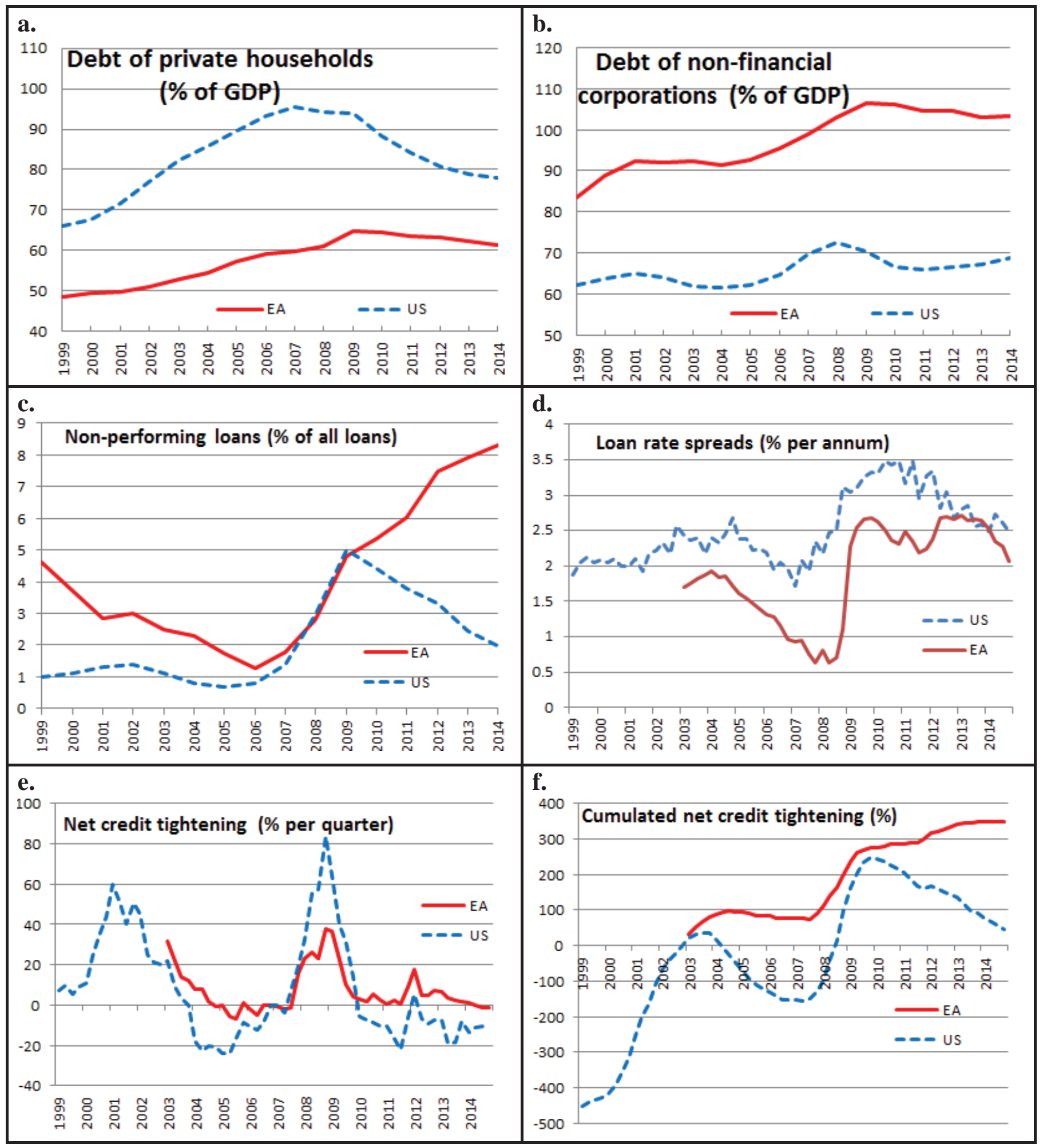

Figure 2. Financial indicators, EA and US.

Non-performing bank loans, bank loan rate spreads and net credit tightening for US pertain to commercial and industrial loans; the same variables for the EA pertain to loans to non-financial corporations. The non-performing loan rate (from World Bank Development indicators) is expressed as \% of total outstanding loans. The loan rate spread is defined as the loan rate (to nonfinancial corporations) minus the money market rate. The net credit tightening measures are based on Fed \& ECB bank surveys (percent of banks that report a tightening of lending standards minus percent of banks reporting loosening of standards); the EA series starts in 2003q1. The cumulated net credit tightening series for the US is (additively) normalized at zero for 2002 q4. 


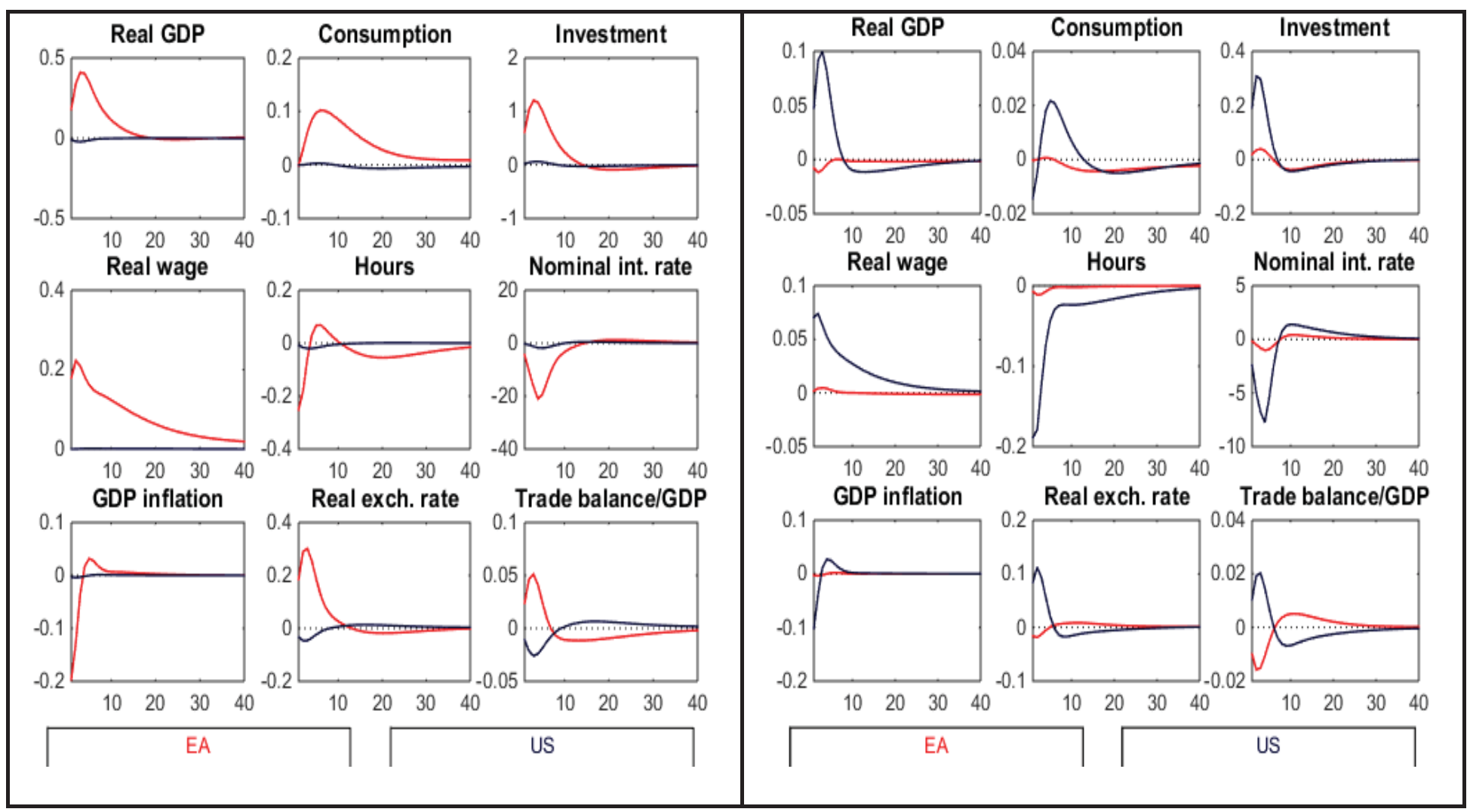

Fig. 3a. Dynamic responses to a transitory positive TFP shock in EA [US]: left [right] Panel
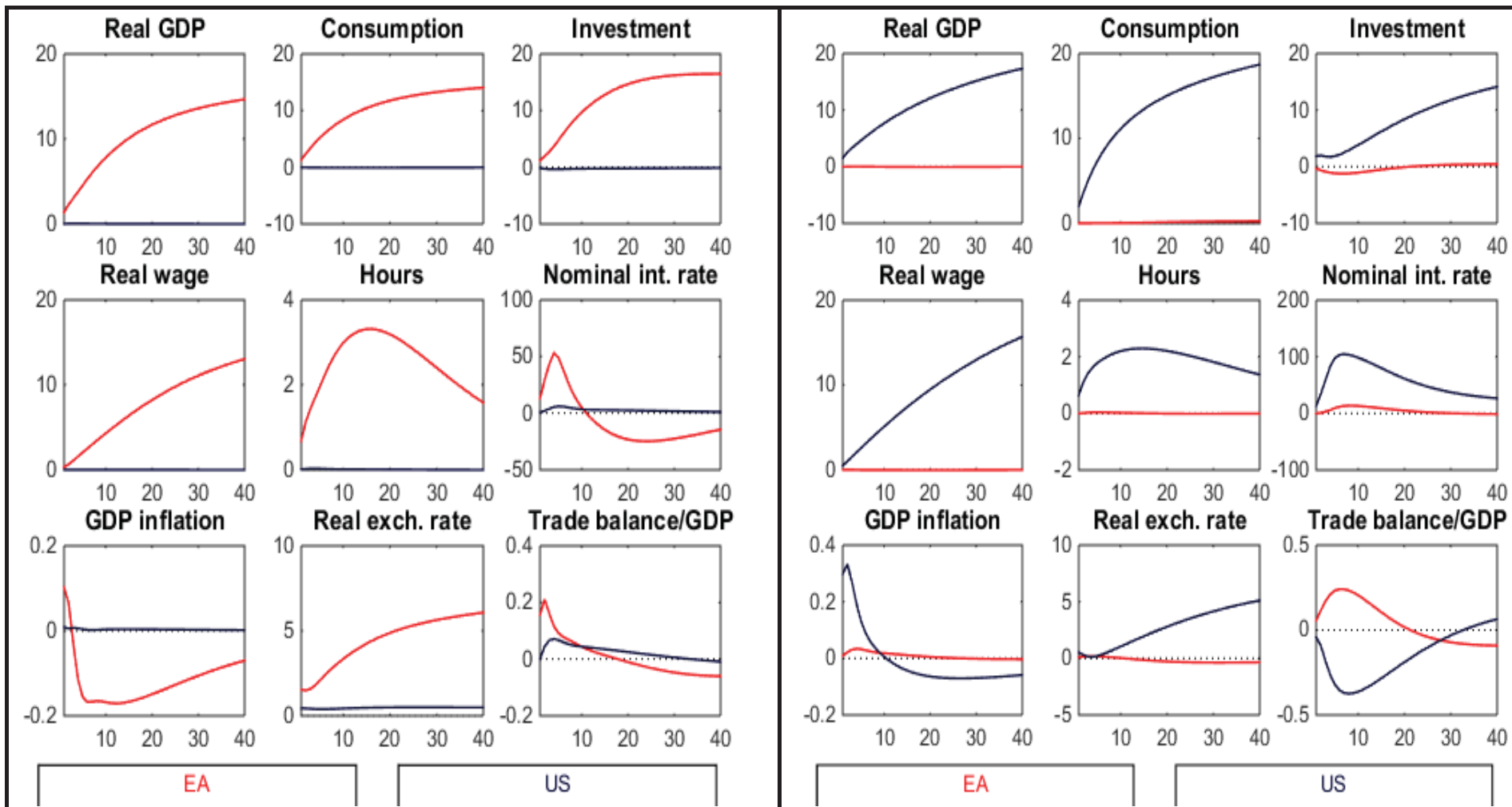

Trade balance/GDP
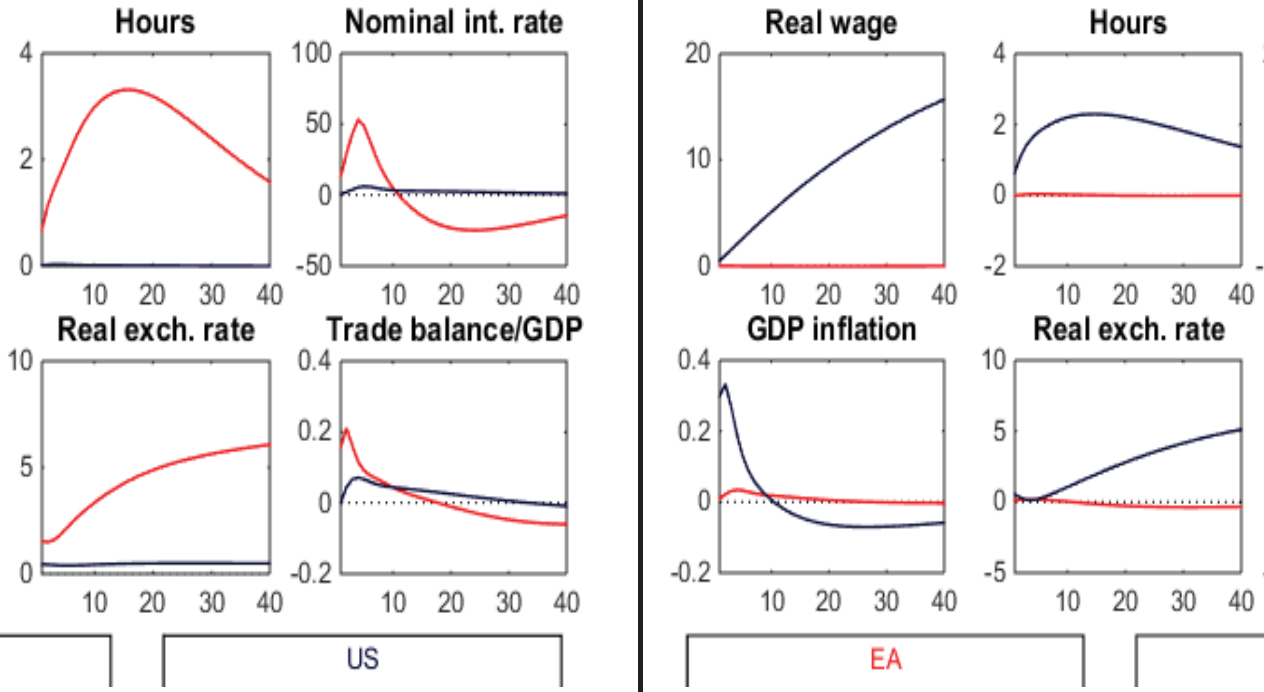

Nominal int. rate
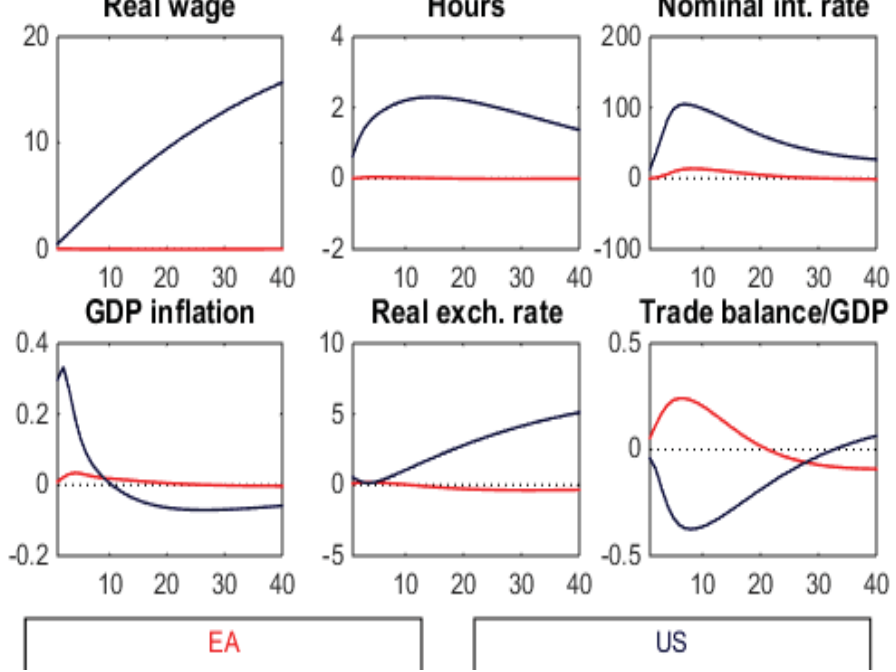

Fig. 3b. Dynamic responses to a positive permanent TFP (growth rate) shock in EA [US]: left [right] Panel 


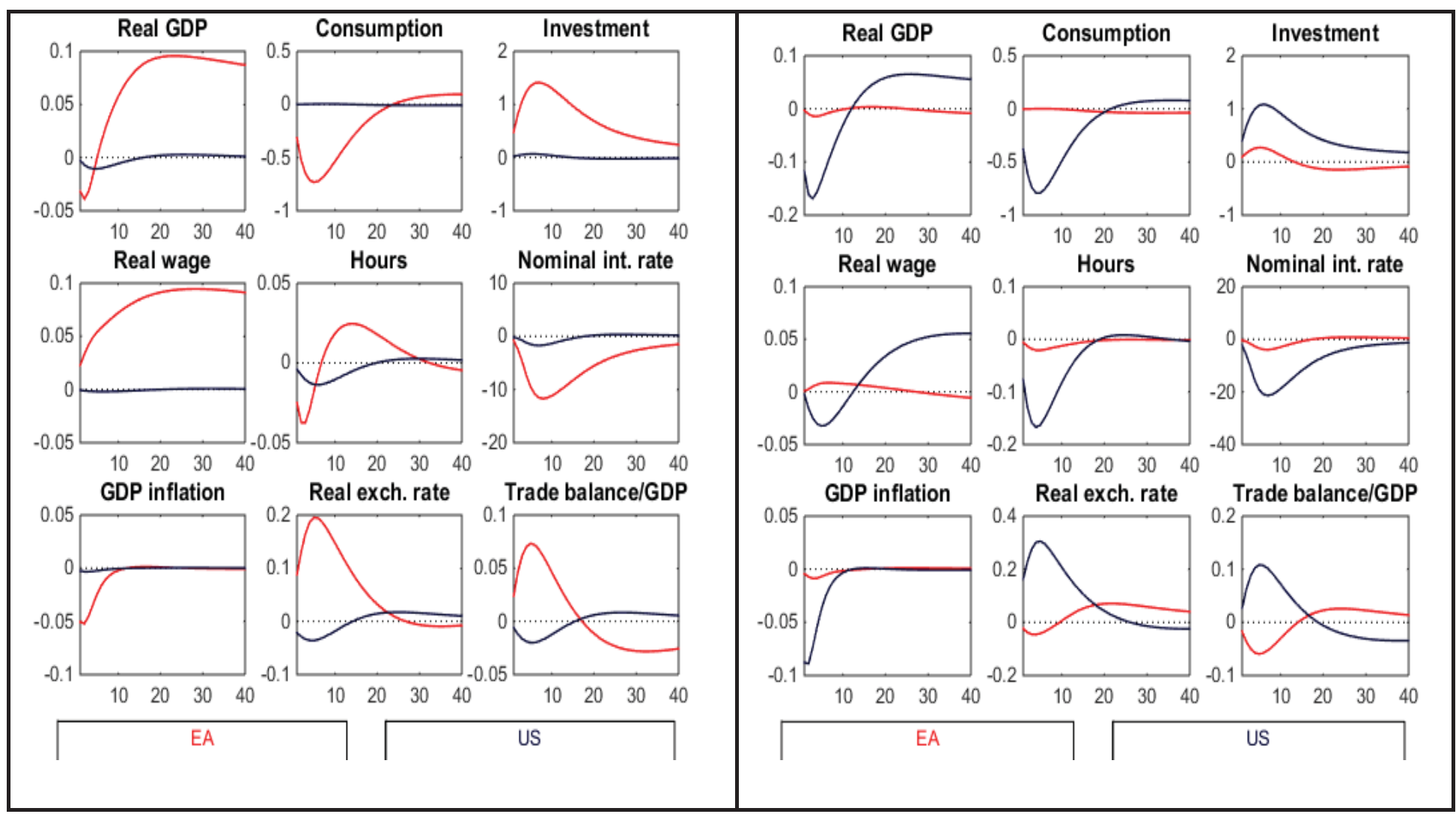

Fig. 3c. Dynamic responses to positive private saving shock in EA [US]: left [right] Panel

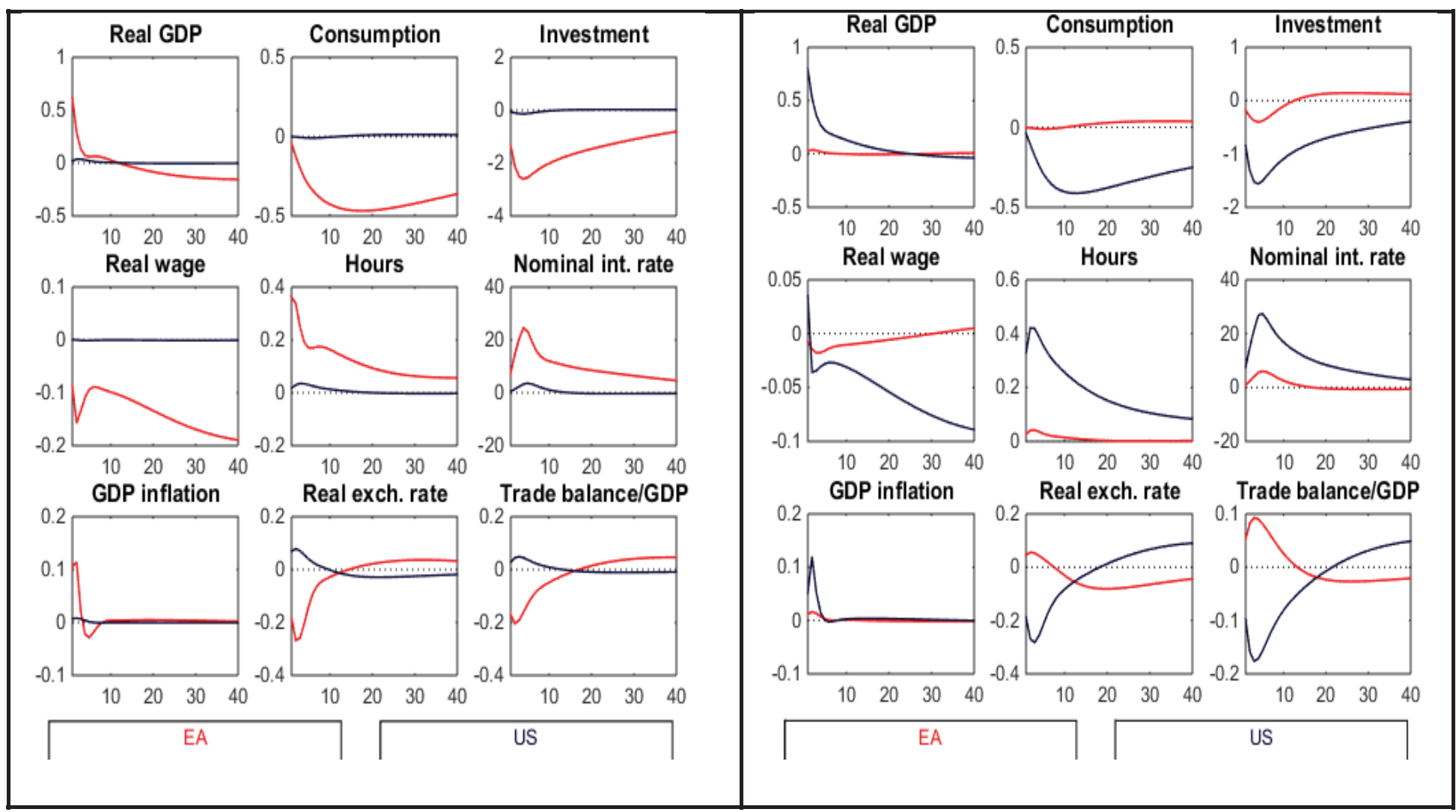

Fig. 3d. Dynamic responses to positive government purchases shock in EA [US]: left [right] Panel 


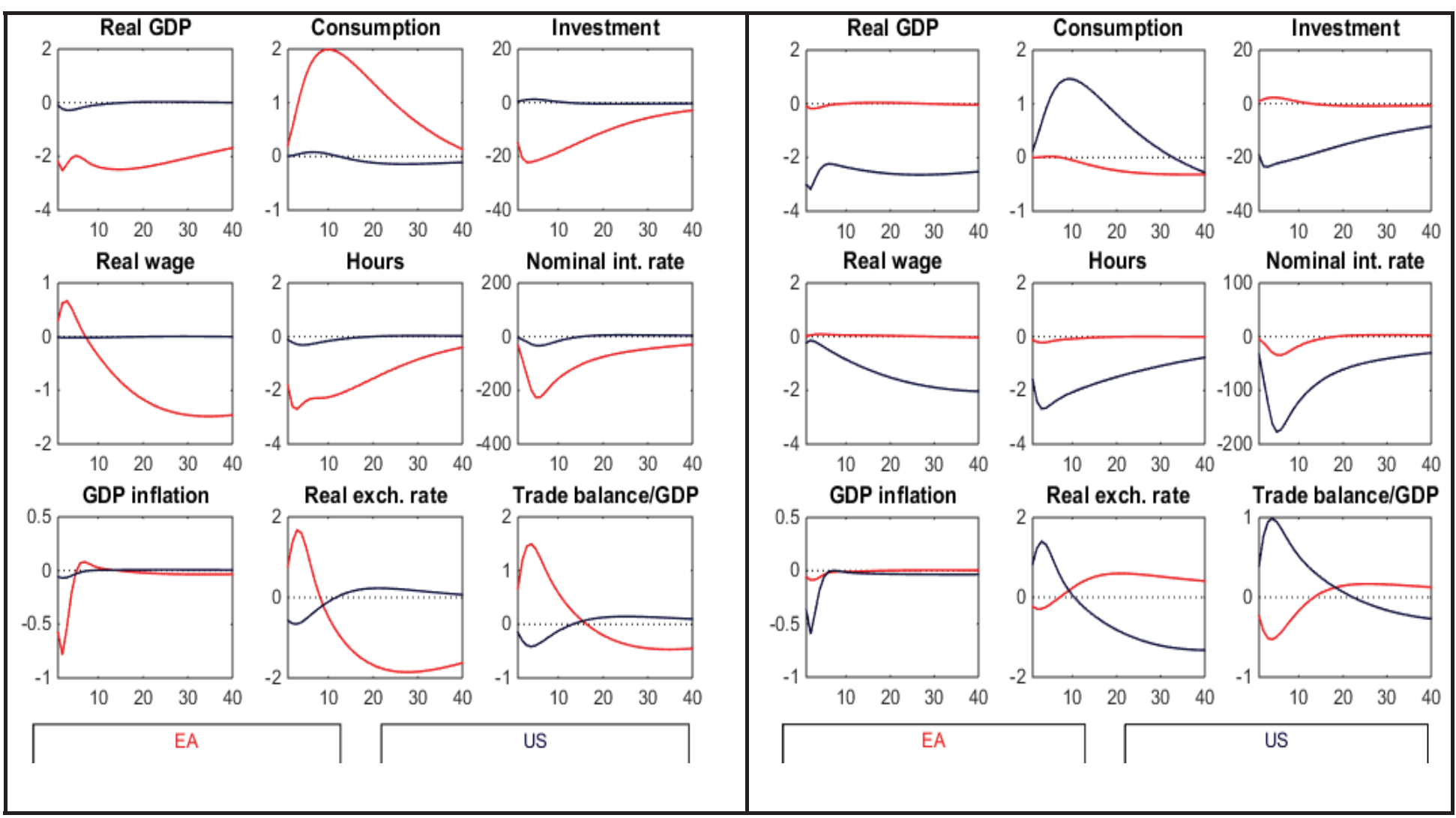

Fig. 3e. Dynamic responses to positive shock to investment risk premium in EA [US]: left [right] Panel

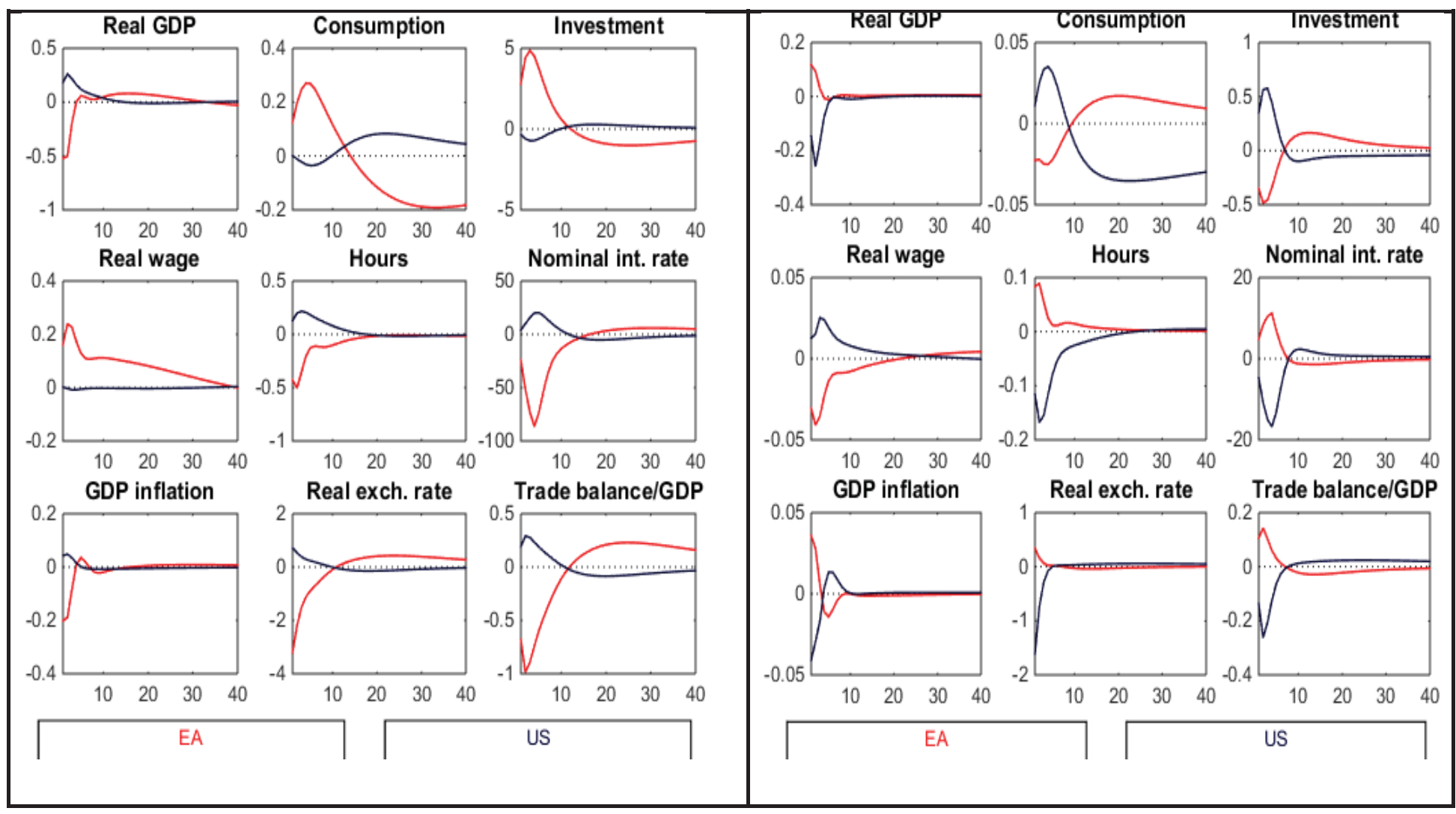

Fig. 3f. Dynamic responses to UIP shock between the EA [US] and the ROW: left [right] Panel 


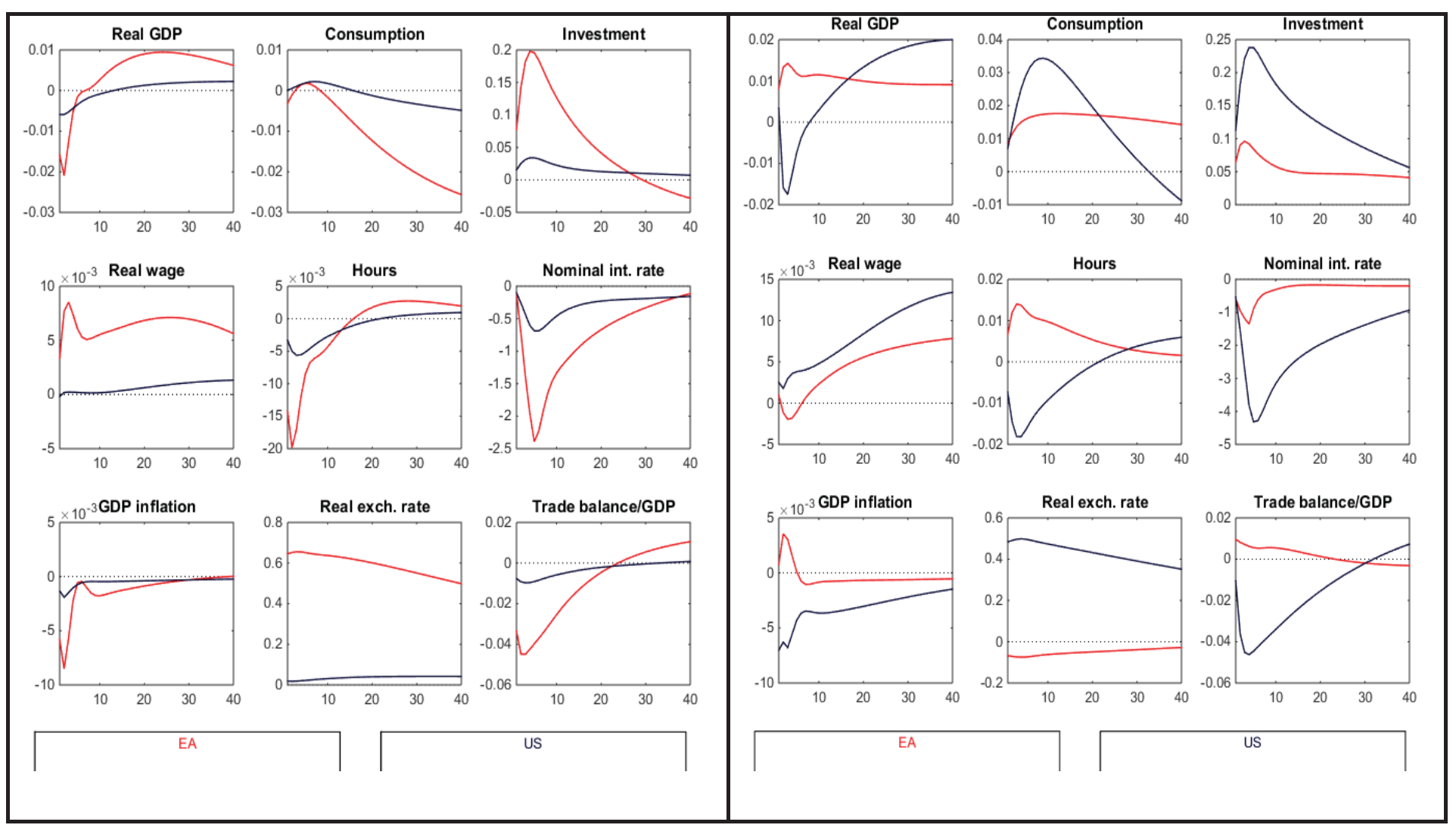

Fig. 3g. Dynamic responses to positive shock to ROW export competitiveness w.r.t. EA [US]: left [right] Panel

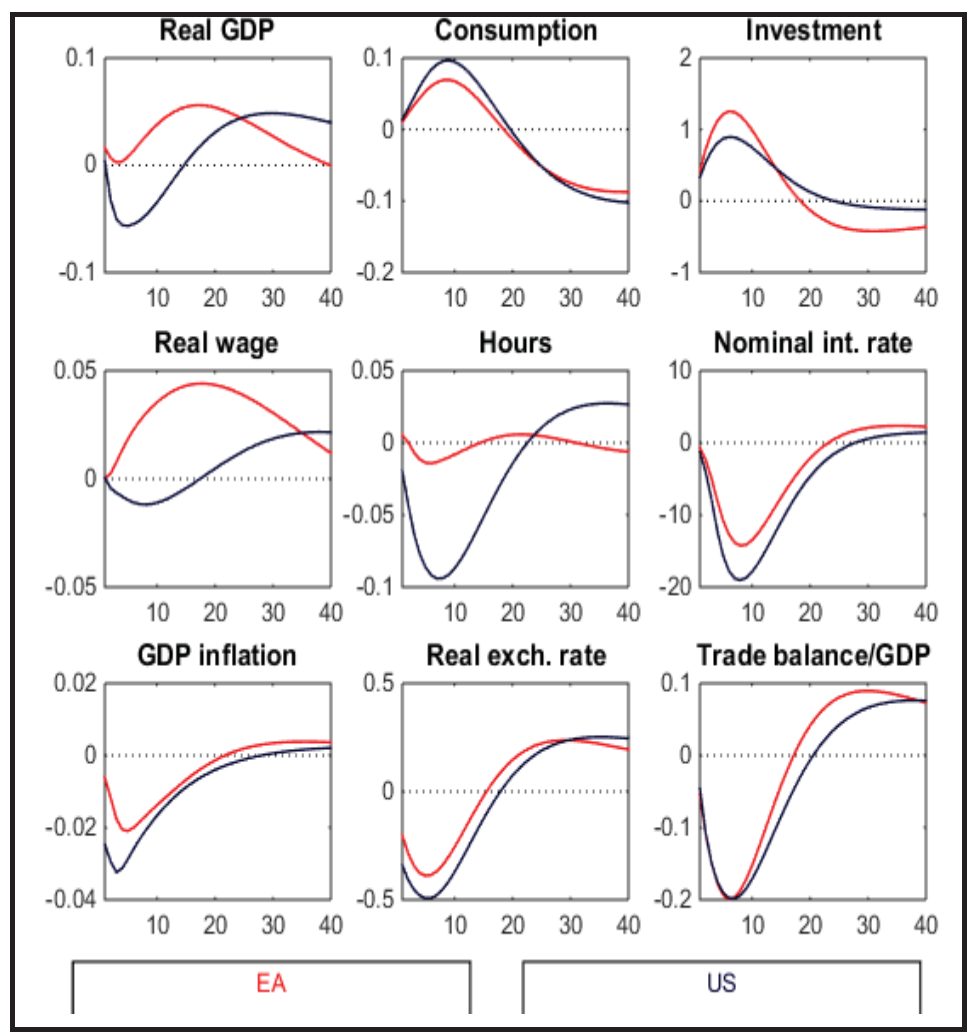

Fig. 3h. Dynamic responses to positive private saving shock in ROW 


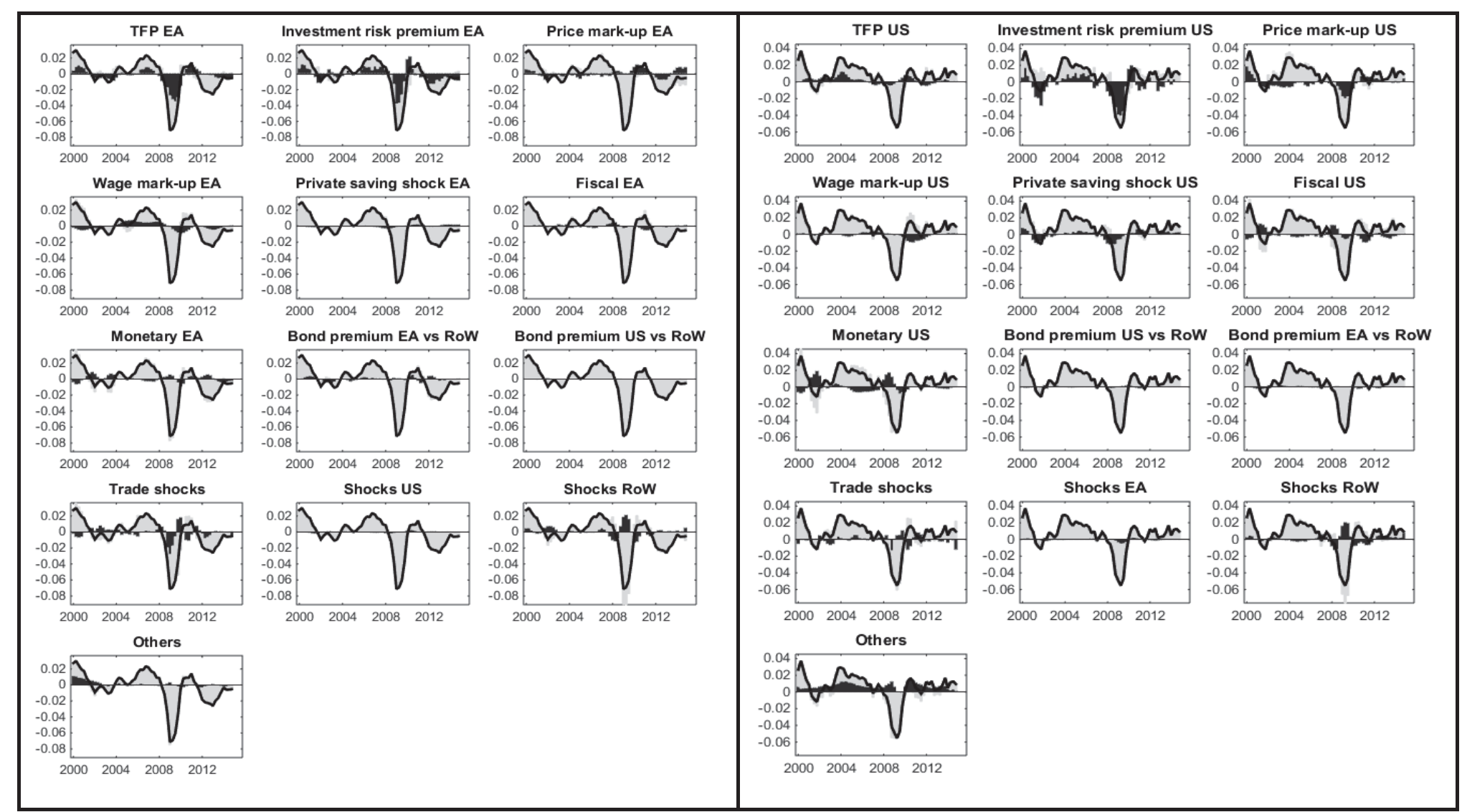

Fig. 4a. Historical decompositions of real GDP growth rate (year-on-year) in EA [US]: left [right] Panel

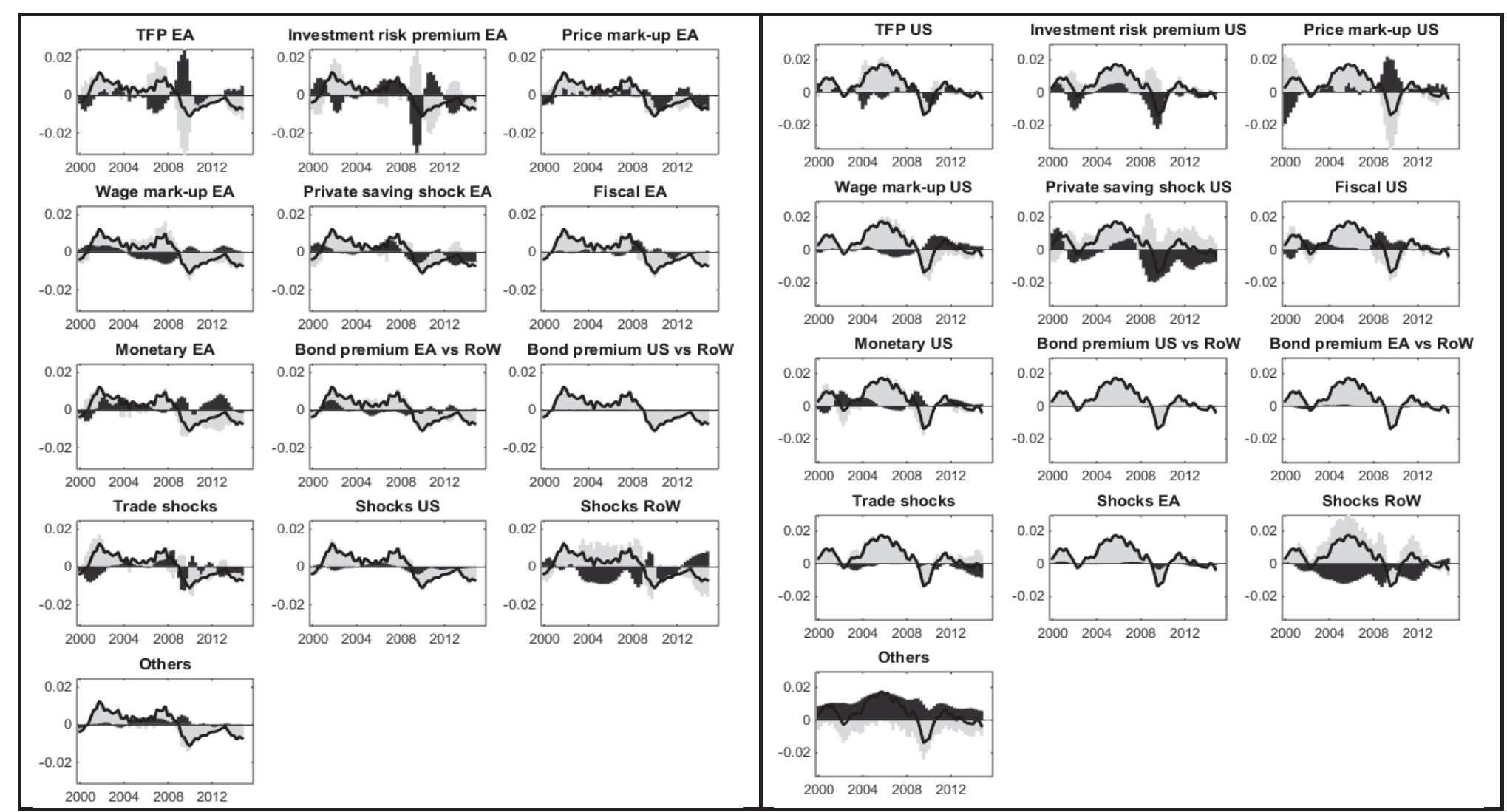

Fig. 4b. Historical decompositions of growth rate (YoY) of GDP deflator in EA [US]: left [right] Panel 


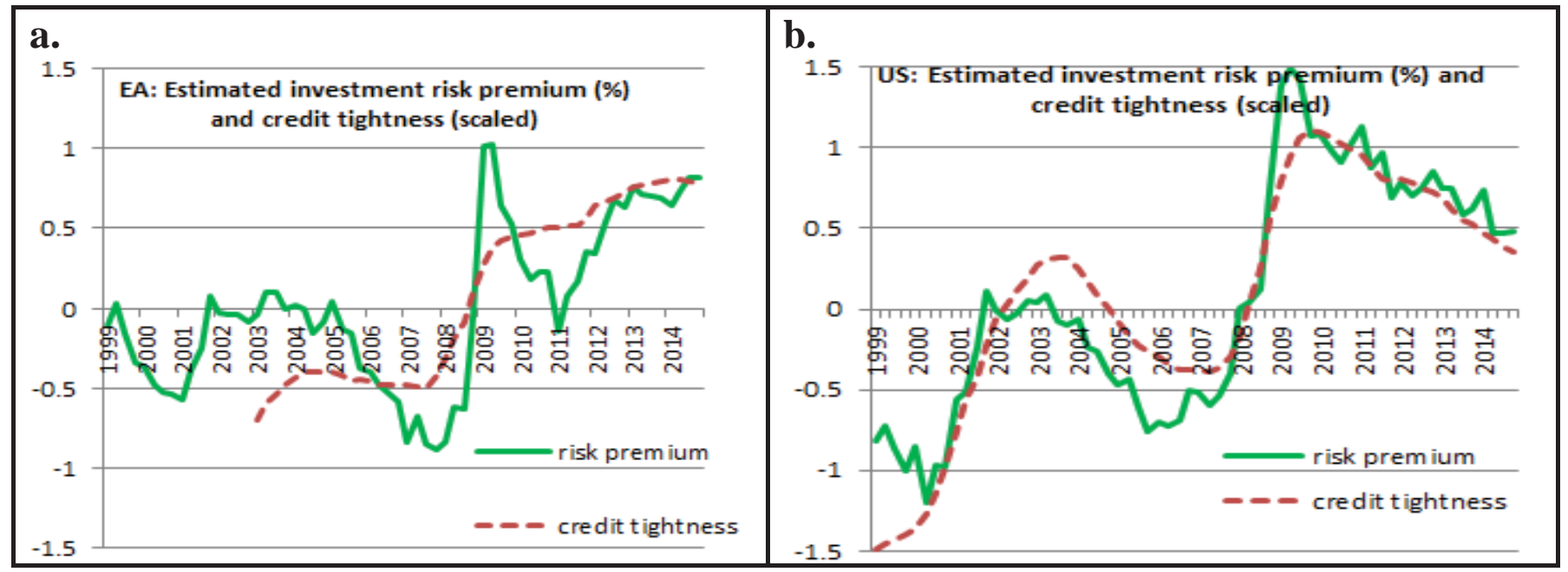

Fig. 5 Estimated investment risk premium and cumulated net credit tightening (scaled) for the EA and the US Notes: Panels a. and b. pertain to the EA and the US, respectively. Empirical cumulated net credit tightening shown in the Figure are adjusted (using a linear transformation) so that the mean and standard deviation of the adjusted series equals the corresponding moments of the estimated investment risk premium. 


\section{APPENDIX: DATA}

\section{Data sources}

Data for the EA (quarterly national accounts, fiscal aggregates, quarterly interest and exchange rates) are taken from Eurostat. Corresponding data for the US come from the Bureau of Economic Analysis (BEA) and the Federal Reserve. Bilateral trade flows are based on trade shares from the GTAP trade matrices for trade in goods and services. ROW series are constructed on the basis of the IMF International Financial Statistics (IFS) and World Economic Outlook (WEO) databases.

\section{Constructing of data series for ROW variables}

Series for GDP and prices in the ROW starting in 1999 are constructed on the basis of data for the following 58 countries: Albania, Algeria, Argentina, Armenia, Australia, Azerbaijan, Belarus, Brazil, Bulgaria, Canada, Chile, China, Colombia, Croatia, Czech Republic, Denmark, Egypt, Georgia, Hong Kong, Hungary, Iceland, India, Indonesia, Iran, Israel, Japan, Jordan, Korea, Lebanon, Libya, FYR Macedonia, Malaysia, Mexico, Moldova, Montenegro, Morocco, New Zealand, Nigeria, Norway, Philippines, Poland, Romania, Russia, Saudi Arabia, Serbia, Singapore, South Africa, Sweden, Switzerland, Syria, Taiwan, Thailand, Tunisia, Turkey, Ukraine, United Arab Emirates, United Kingdom, and Venezuela. The ROW data are annual data from the IMF International Financial Statistics (IFS) and World Economic Outlook (WEO) databases.

For details about the construction of ROW aggregates, see the Not-for-Publication Appendix.

\section{List of observables}

The estimation uses the following time series for both the EA and the US: GDP, GDP deflator, population, total employment, employment rate, employment in hours, participation rates, relative prices with respect to GDP deflator (VAT-consumption, government consumption, private investment, export, and import), government investment price relative to private investment, nominal policy rate, and nominal shares of GDP (consumption, government consumption, investment, government investment, government interest payment, transfers, public debt, wage bill and exports). The list of observables also includes the oil price and the US exchange rate with respect to EA and ROW. For the ROW we use data on population, GDP, GDP deflator and the nominal policy rate. 